



\section{FIELDIANA Anthropology}

Published by Field Museum of Natural History

Volume 70

E.W. NELSON'S NOTES ON THE INDIANS OF THE YUKON AND INNOKO RIVERS, ALASKA

Edited with an introduction by

JAMES W. VANSTONE

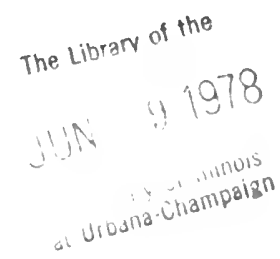

April 28, 1978 





\title{
FIELDIANA: ANTHROPOLOGY
}

\author{
A Continuation of the \\ ANTHROPOLOGICAL SERIES \\ of
}

FIELD MUSEUM OF NATURAL HISTORY

VOLUME 70

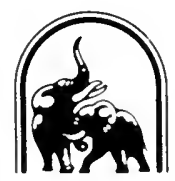

FIELD MUSEUM OF NATURAL HISTORY

CHICAGO, U.S.A. 

E.W. NELSON'S NOTES ON THE INDIANS OF THE YUKON AND INNOKO RIVERS, ALASKA 


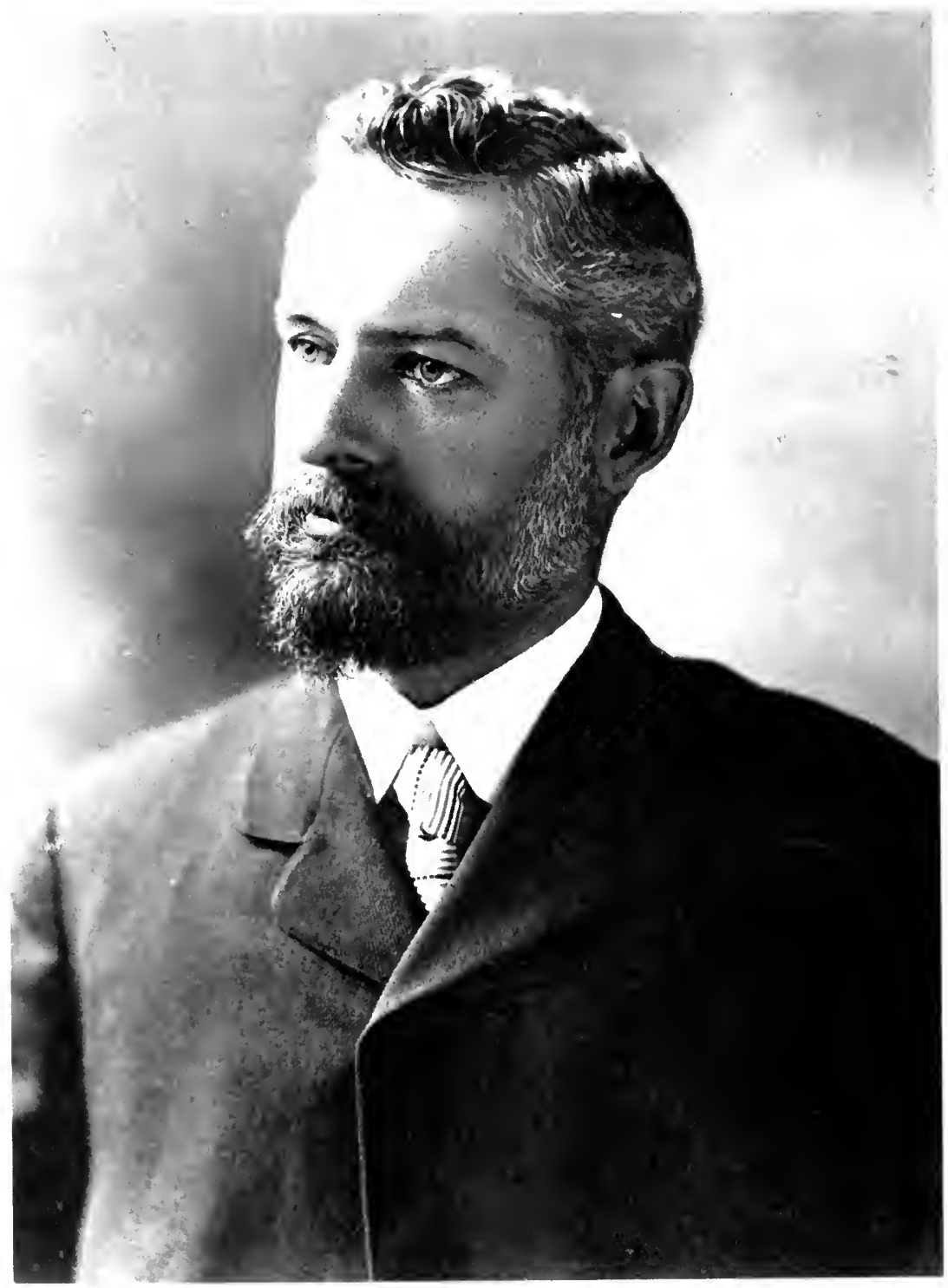

FrontisPiECE: Edward William Nelson, 1855-1934. (Smithsonian Institution, National Anthropological Archives). 


\section{FIELDIANA Anthropology}

Published by Field Museum of Natural History

Volume 70

\section{E. W. NELSON'S NOTES ON THE INDIANS OF THE YUKON AND INNOKO RIVERS, ALASKA}

Edited with an introduction by

JAMES W. VANSTONE

Curator, North A merican Archaeology and Ethnology

Field Museum of Natural History

April 28, 1978

Publication 1281 
Library of Congress Catalog Card No.: 77-091447

ISSN 0071-4739

PRINTED IN THE UNITED STATES OF AMERICA 


\section{CONTENTS}

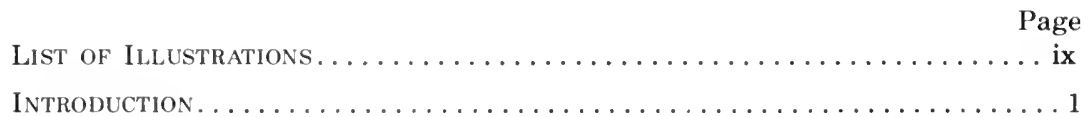

Preface to Nelison's Account. ........................... 16

E.W. NELSON'S NOTES ON INDIANS OF THE YUKON

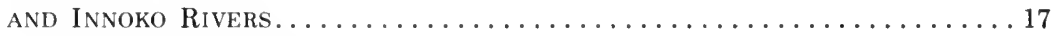

Messenger or barter festival. . . . . . . . . . . . . . . . . . . 17

Festival to the dead .............................. 18

Festival of the dressing of the dead . . . . . . . . . . . . . . . 21

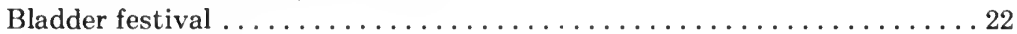

Anvik doll festival . . . . . . . . . . . . . . . . . . . . . 25

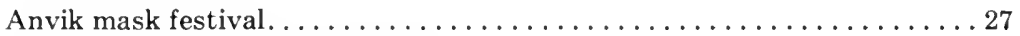

Burial customs of Yukon Indians. . . . . . . . . . . . . . 28

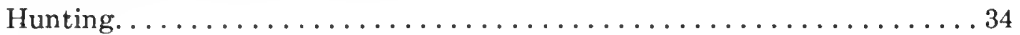

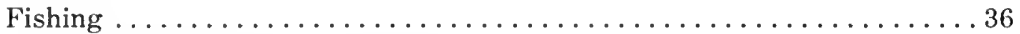

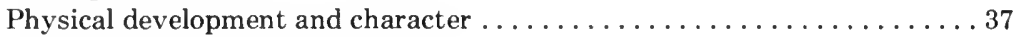

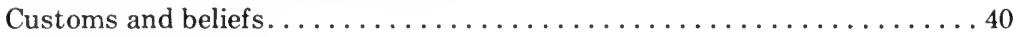

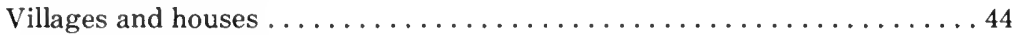

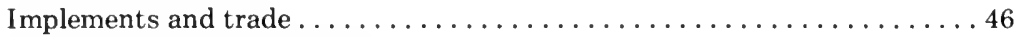

Raven tale of the stolen wife......................... 47

Raven's search for his friend's wife ...................... 51

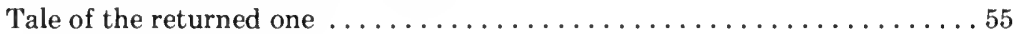

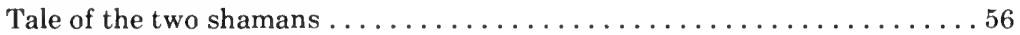

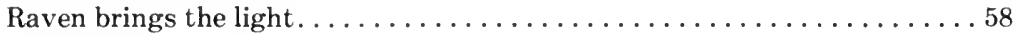

Bird myth . . . . . . . . . . . . . . . . . . . . . 60

Notes . . . . . . . . . . . . . . . . . . . . . . . . . 62

REFERENCES ...................................... 74

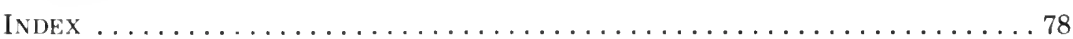





\section{LIST OF ILLUSTRATIONS}

Frontispiece: Edward William Nelson, $1855-1934 \ldots \ldots \ldots \ldots \ldots \ldots \ldots$ iv

1. Map of Alaska ................................. 2

2. Map of the lower-middle Yukon and lower Innoko rivers $\ldots \ldots \ldots \ldots \ldots \ldots$

3. Indian graves on the Innoko River ....................... 32

4. A kashim on the Innoko River...................... 45 



\section{INTRODUCTION}

On November 16, 1880, E. W. Nelson, Signal Service observer at St. Michael, and a companion, S. A. Fredericks, a fur trader stationed at Anvik, left St. Michael with dogs and sledges for a trip to the lower-middle Yukon River and its major tributary in this area, the Innoko.

Europeans and Americans had been in the Yukon area and even on the Innoko for nearly 50 years, but the tributaries of the lower Yukon and their inhabitants were almost as little known in 1880 as they had been at the conclusion of Lieutenant Lavrentiy A. Zagoskin's explorations for the Russian-American Company 35 years before. Nelson's manuscript account of this trip, published here for the first time, therefore fills a large gap in our knowledge of the area.

Russian explorers may have reached the Yukon River overland from Cook Inlet as early as the 1790's (Chernenko, 1967, pp. 9-10, 29-30; Fedorova, 1973a, p. 6) or from Iliamna Lake in 1818 (Fedorova, 1973b, pp. 64-68), but it was not until 1833 when the Russian-American Company established Mikhailovskiy Redoubt near the mouth of the Yukon that they were able to penetrate the interior of Alaska via its major river. After unsuccessful explorations in the Yukon Delta that same year, Andrey Glazunov, a creole employee of the company, was chosen to lead a small expedition overland in January, 1834. His journey, a major accomplishment in the history of Alaskan exploration, resulted in the first account of the Yukon Valley and its inhabitants.

Glazunov ascended one of the streams flowing into Norton Sound east of Mikhailovskiy Redoubt, crossed over to the upper Anvik

${ }^{1}$ Although primarily a product of historical research, this paper has benefited from my two seasons of field work in the lower Yukon-Innoko area supported by the Wenner-Gren Foundation for Anthropological Research and the James R. Getz Fund of Field Museum of Natural History. For critical comments and helpful sug. gestions during the preparation of this paper, I am grateful to Dorothy Jean Ray and my wife, Mary W. Helms. The maps were drawn by Zbigniew Jastrzebski. 


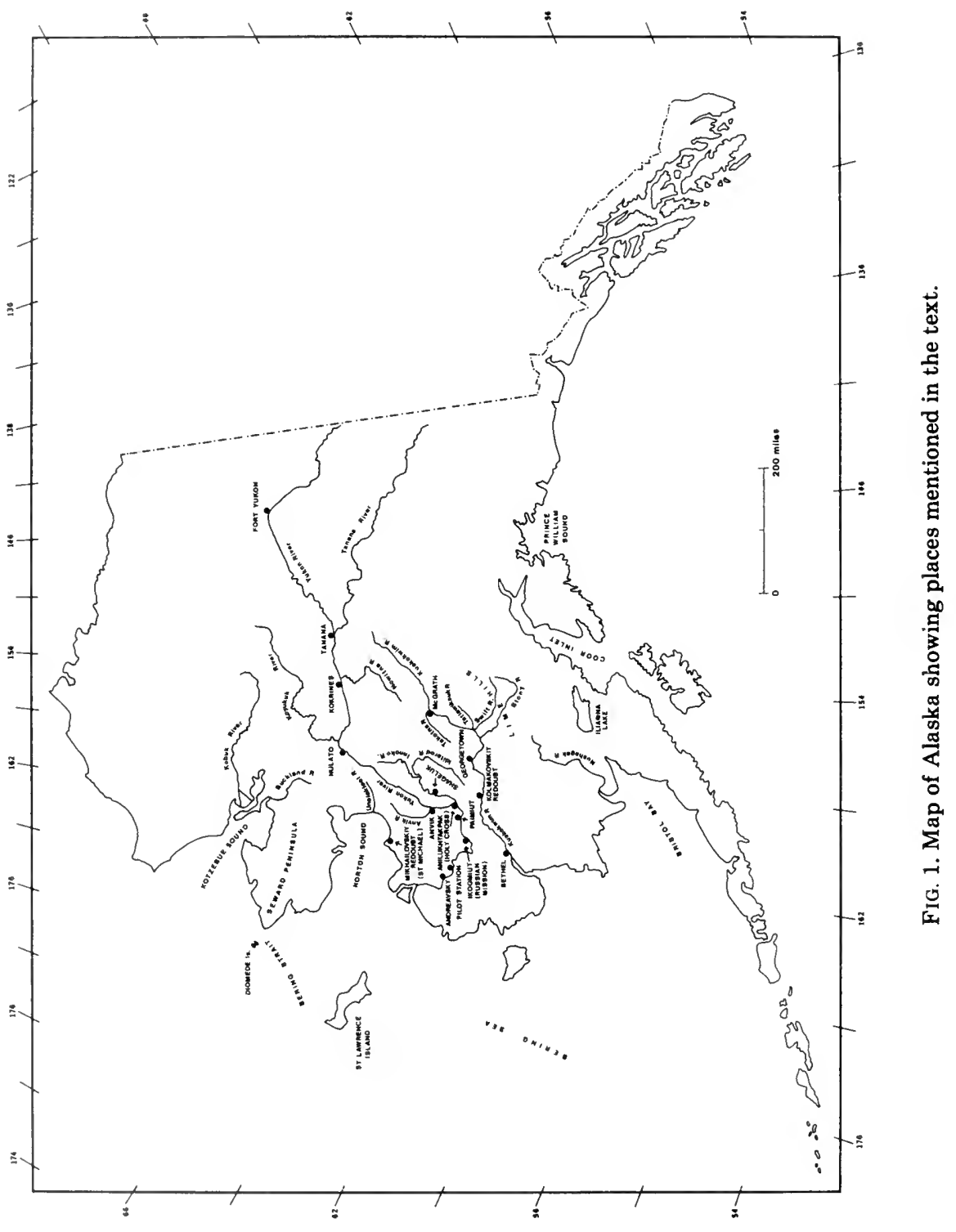


River, a major tributary of the lower-middle Yukon, and descended it to the Ingalik Indian village of Anvik at the mouth. After distributing trade goods and exhorting the Indians to bring their furs to Mikhailovskiy to trade, Glazunov proceeded down the Yukon trading, and taking a similar message to the inhabitants of Magimiut (Bonasila) and Anilukhtakpak (near Holy Cross). From Anilukhtakpak he proceeded over the portage to the Kuskokwim River and reached the company's small trading post, later known as Kolmakovskiy Redoubt, in mid-February. In an attempt to reach Cook Inlet, Glazunov ascended the Kuskokwim and the Stony River as far as the Lime Hills, but was forced to turn back after experiencing extreme hardship and starvation. His return route is not definitely known, but was probably by way of the Kuskokwim. In any event, Glazunov and his party arrived back at Mikhailovskiy Redoubt in mid-April (VanStone, 1959).

Glazunov's account, which has never been published in full (Fedorova, 1973b, p. 31), provides the first ethnographic information concerning the Ingalik, westernmost members of the Athapaskan language family, and his explorations, together with those of other explorers in the Nushagak and Kuskokwim drainages (VanStone, 1967, pp. 3-11), served to open all of southwestern Alaska to the fur trade. Glazunov's success led to further exploration of the Yukon Delta and to the establishment of a trading post at Ikogmiut in 1836. Of equal significance, it also led to Petr Vasilevich Malakhov's travels on the upper-middle Yukon for the purpose of extending the fur trade in that direction

Malakhov, like Glazunov an employee of the Russian-American Company, left Mikhailovskiy Redoubt in February, 1838 and reached the Yukon by way of the Unalakleet River portage. He ascended as far as the mouth of the Koyukuk and was undoubtedly the first European to see that river. After establishing the Nulato trading post, he descended the Yukon to its mouth the next spring, and was thus the first Russian to navigate a significant portion of its great length. During his descent he apparently entered Shageluk Slough and may have continued down the lower Innoko to its confluence with the Yukon. If so, he was probably the first Russian to navigate any portion of that important Yukon tributary (Chernenko, 1967, p. 10; Zagoskin, 1967, p. 298).

By 1839 the Russians were reasonably familiar with the Unalakleet and Anvik rivers, the Yukon between Nulato and its 
mouth, and considerable portions of the Kuskokwim and Nushagak drainages. The Russian-American Company now needed to fill gaps in its knowledge of the interior of west-central Alaska by obtaining more information concerning the area between the Yukon and Kuskokwim drainage systems. Glazunov had failed to bridge this particular geographical gap, being unable to reach Cook Inlet by way of the Stony River, so it was still necessary to explore a route from the Kuskokwim to the Yukon well above the usual portages and at the same time to obtain first-hand information concerning the potentially rich fur-bearing area of the Innoko River and its tributaries.

In the fall of 1839 Petr Fedorovich Kolmakov, son of Fedor Kolmakov, pioneer explorer of the Kuskokwim and Nushagak rivers, crossed over from the Takotna, a tributary of the Kuskokwim below the present village of McGrath, to the upper reaches of the Innoko which he called the Tlëgon. His journal indicates that he collected a large number of beaver pelts and descended the Innoko in search of a short route to the Yukon. At some point during his journey, probably at the village of Dementi opposite the mouth of the Iditarod River, a major Innoko tributary, Kolmakov learned that the post at Ikogmiut had been attacked and destroyed, and the occupants massacred in the spring of 1839 . He was therefore obliged to turn back. It is not clear whether this attack was perpetrated by the natives of the Kuskokwim or the lower Yukon, but it seems likely that Kuskokwim Eskimos from near the present village of Bethel were responsible. Destruction of the post may have been in retaliation for the disastrous smallpox epidemic of 1838-1839 for which the Indians and Eskimos of western Alaska held the Russians responsible (Chernenko, 1967, p. 10; Zagoskin, 1967, pp. 81, 236-237, 275, 300; Russian-American Company records, communications sent, vol. 20 , no. 486, folios 403-404, October 15, 1841).

The next Yukon exploration of major importance was that of naval lieutenant Lavrentiy Alekseyevich Zagoskin for the RussianAmerican Company from 1842 to 1844. In the administration's orders to Zagoskin he was directed to explore the Yukon, Kuskokwim, and Innoko rivers, to ascertain the most practical portages between these rivers, and to explore the drainage of the Buckland River which was known to flow into Kotzebue Sound. Zagoskin's expedition left Mikhailovskiy Redoubt on December 4, 
$1842^{1}$ and proceeded to the Yukon by way of the Unalakleet River, the route pioneered by Malakhov. Arriving at Nulato in midJanuary, 1843, his party, during the winter, explored the lower Koyukuk searching for a short route to the Buckland River and Kotzebue Sound. Zagoskin eventually abandoned this part of his planned exploration since he had neither the time nor the resources to reconnoiter as far as the coast.

After spending the spring at Nulato collecting natural history specimens and data on the fur trade, Zagoskin's party started up the Yukon on June 4, and explored as far as the mouth of the Nowitna River, just above the present village of Kokrines. Somewhere near Kokrines they met an encampment of upper Innoko Indians, from whom Zagoskin obtained useful information about their area, supplementing data he had already obtained from Petr Kolmakov's map.

On August 2, 1843 Zagoskin and his companions left Nulato after a stay of some seven months, this time going down the Yukon. On August 13 the party arrived near the entrance to Shageluk Slough but being unable to enter because of shallow bars at the entrance, continued to Anvik, Anilukhtakpak, and Ikogmiut, which became Zagoskin's headquarters for the winter of 1843-1844. Thus far he had explored and described more than 500 miles of the Yukon River.

For the purposes of this introduction, Zagoskin's most pertinent explorations during that winter were along the lower reaches of the Innoko, although he also traveled to the Kuskokwim twice. He explored the Innoko between February 10 and March 10, 1844, and, although he describes and names a number of settlements on the river and gives detailed information concerning the environment, it is not possible to determine his route with complete certainty. $\mathrm{He}$ apparently reached the mouth of the Iditarod and believed that he had ascended the river to at least the point that Petr Kolmakov had reached from the opposite direction. Having accomplished this, Zagoskin then realized that it was possible to travel from the upper Kuskokwim to the lower Yukon by way of the Innoko, although this route was obviously longer and more difficult than the short, customary portages leading from the Yukon River settlements of Paimiut and Ikogmiut.

'Dates are according to the Georgian calendar which was 12 days behind the Julian in the nineteenth century. 
Having completed their Kuskokwim explorations, Zagoskin and his party were back in Ikogmiut on June 10, 1844 for the last time, and left on the 13th. They descended the Yukon to its mouth, making their way along the coast to Mikhailovskiy Redoubt where they arrived on June 21, having been away from the post for more than a year and a half.

Zagoskin's report, first published in 1847-1848, republished in a carefully edited edition in 1956, and in an English translation in 1967, is the primary source for information on the history, geography, and ethnography of west-central Alaska during the Russian period. The Russian-American Company made no further attempts at comprehensive interior exploration. Traders stationed at Mikhailovskiy and Ikogmiut visited the Indian villages periodically to collect furs, and a priest from the Russian Orthodox mission, which was established at Ikogmiut in 1845 , also traveled extensively. Although they experienced extensive contact with village inhabitants, it is doubtful whether, in the course of their travels, they added greatly to the knowledge which the company already possessed concerning the country and its inhabitants.

At the time of the transfer of Alaska from Russia to the United States in 1867 American explorers were already in the newly acquired territory. Members of the Western Union Telegraph Company Expedition, an elaborate undertaking to survey a route for a telegraph line that would cross the Bering Sea to Siberia and thus connect America with Europe, were at Mikhailovskiy Redoubt in the winter of 1865 and at Nulato in the spring of the following year. Although the lower-middle Yukon and the Innoko were traversed, the various parties did little more than pass through these areas and they seem to have been largely unaware of previous explorations. Nevertheless, members of the Telegraph Expedition could not help noting that the Indians with whom they came in contact were familiar with white men and had established procedures for dealing with them. In various publications relating to the work of the expedition references are made to the fur trade and useful information is sometimes provided concerning the early stages of culture change in the Yukon-lower Innoko area (Whymper, 1869, pp. 264-265; Dall, 1870, pp. 219-222).

In the summer of 1869 Captain Charles W. Raymond, U.S. Corp of Engineers, traveled from St. Michael, as Mikhailovskiy was called after the purchase, to Fort Yukon in a small steamer to ascertain 
the amount of trade carried on by the Hudson's Bay Company in American territory and to determine the latitude and longitude of that post. Like members of the Telegraph Expedition, Raymond makes useful contributions to our knowledge of the fur trade at the beginning of the American period, but he spent very little time in the area of interest to us here. He noted the existance of Shageluk Slough, but made no attempt to explore in that direction and only commented that the Innoko Valley was reported to be the richest fur country in the lower Yukon (Raymond, 1871, 1873).

In summary, much of the exploration of interior Alaska by both Russians and Americans between 1845 and 1880 was superficial and was not accompanied by the accurate surveying and mapping that characterized some coastal explorations being carried out at the same time. Writing as late as 1886 , Henry W. Elliott, a noted authority on Alaska and former member of the Western Union Telegraph Company Expedition, noted that although the Yukon flowed through some of the most unexplored country in the north, the river itself was one of the best known waterways in Alaska (Elliott, 1886, pp. 412-413).

St. Michael was one of the early stations of the Signal Service of the United States Army in Alaska. This program was established in 1874, largely through the efforts of Spencer Baird, then Secretary of the Smithsonian Institution. The observers selected for these stations were young men interested in all aspects of natural history and thus qualified to make profitable use of their time when not performing their meteorological duties. In June, 1877 Private Edward William Nelson was assigned to St. Michael and directed by the Chief Signal Officer to obtain, in addition to weather observations, data on the geography, ethnology, and zoology of the area (Sherwood, 1965, pp. 93-94).

Edward Nelson was born near Manchester, New Hampshire on May 8, 1855.' The family moved to Chicago following his father's death in the Civil War. Intermittently between 1872 and 1875 he attended the Cook County Normal School and at the age of 17 made his first field collecting trip to the far west. His principal interest at this time and throughout the early years of his career was orni-

'A detailed account of Nelson's life stressing his accomplishments in the fields of ornithology and mammology is found in Goldman (1935). His anthropological contributions are described and evaluated by Lantis (1954). 
thology and his first papers, on birds of Illinois, were published in 1876 and 1877.

With the assistance of Baird, Nelson was accepted as a weather observer in the Signal Service for assignment to Alaska and in April, 1877 he sailed from San Francisco. During his term of duty at St. Michael he traveled extensively and, in addition to collecting birds and mammals, made the superb collection of Eskimo ethnographic specimens, now in the National Museum of Natural History, which has secured his fame among later generations of arctic anthropologists.

Nelson remained at St. Michael until 1881 and his last journey during the winter prior to his departure is the subject of this account. Leaving St. Michael on November 16, 1880 with dogs and sledges, Nelson and Fredericks crossed the mountains to the upper Anvik River, and thence down the river to its confluence with the Yukon. After being delayed at Anvik a few days because of bad weather, the two men traveled up the Yukon a short distance before crossing overland to the Innoko River and exploring its upper reaches (Nelson, 1887, p. 16; 1899, p. 20).

The exact route traveled by Nelson and his companion is uncertain in part because his accounts, both published and unpublished, are sketchy and vague on this subject, but also because of certain geographical characteristics of the area. About 75 miles above its confluence with the Yukon the Innoko is joined to the latter by Shageluk Slough, an anabranch which runs in a meandering north -south direction generally parallel to the two rivers for a distance of some 40 miles and joins the Innoko approximately 15 river miles above the village of Shageluk. A branch of Shageluk Slough, Holikachuk Slough, flows into the Innoko above the village of Holikachuk, formerly a sizeable settlement but abandoned in the 1960 's when the inhabitants moved to the Yukon.

A glance at the map (fig. 2) will show that Shageluk Slough, together with the Innoko River, creates a large island roughly in the shape of an inverted triangle with Fox Point Island in the northwest corner, Holikachuk in the northeast corner, and the confluence of the Innoko and the Yukon at the apex. This arrangement has created confusion in geographical naming and identification by early explorers, traders, and missionaries. In some written accounts, including Nelson's manuscript, Shageluk Slough is con- 


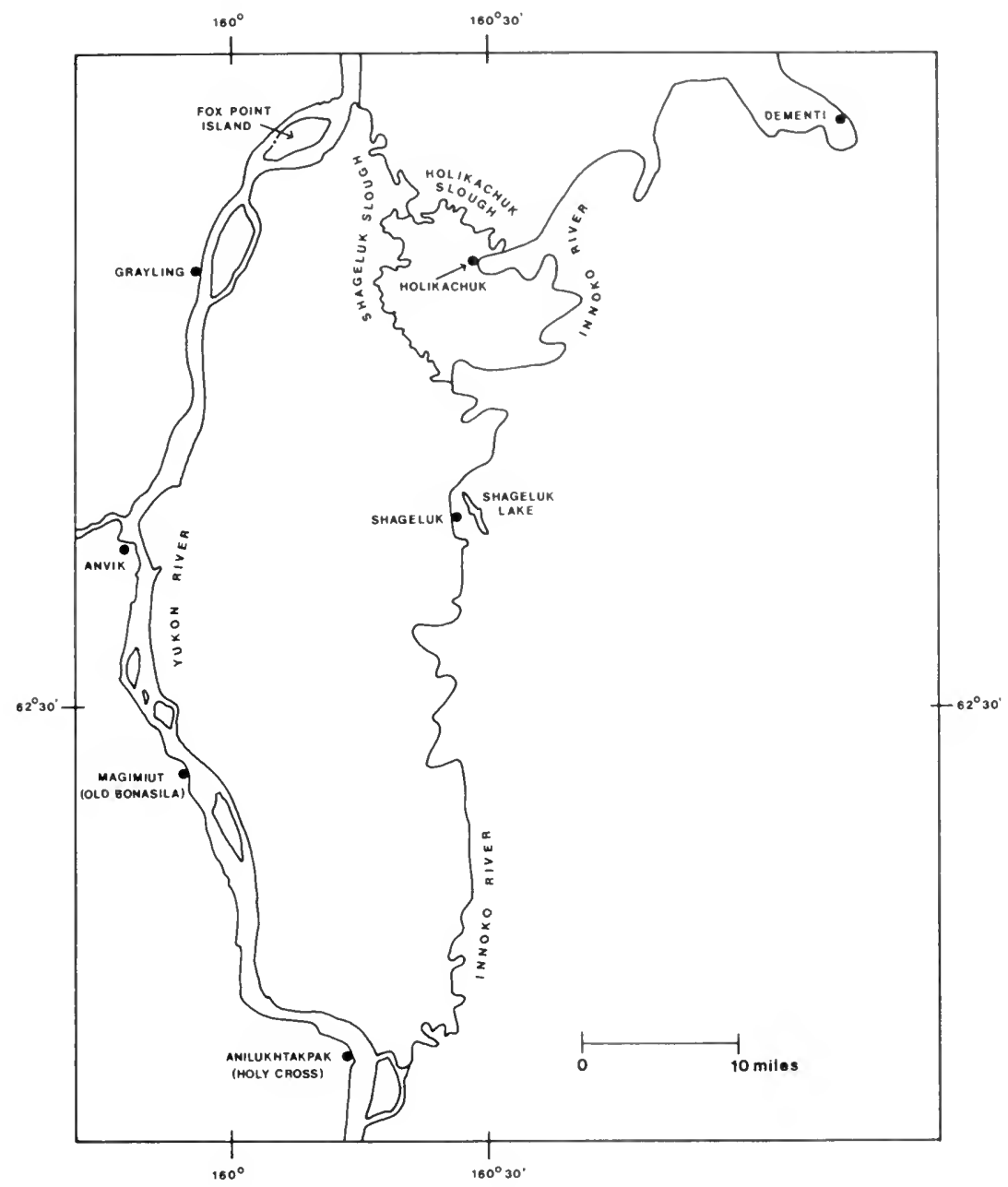

FIG. 2. Map of the lower-middle Yukon and lower Innoko rivers.

sidered to include not only the slough but the lower Innoko as well. For these writers the name Innoko is applied only to the river above the mouth of Holikachuk Slough. It is easy to see why some observers considered the entire complex of sloughs and a section of the lower Innoko to be simply a large anabranch of the Yukon, because it is certainly true that both sloughs deliver a considerable amount of Yukon water to the Innoko in the spring. Zagoskin (1967, p. 298) noted that the Indians he encountered referred to the upper 
Innoko as the Tlëgon, a name, it will be recalled, which Petr Kolmakov also obtained in 1838. The "middle course" was called "Shiltonotno or Innoka," while the lower reaches between the point where Holikachuk Slough enters and its junction with the Yukon was designated "Ittege" by the local people and "Chagelyuk," or Shageluk, by the neighboring Eskimos. Zagoskin believed the name Shageluk to mean "willow," a reference to the heavy growth of these trees along the river's banks. According to one source (Osgood, 1958, p. 27), Innoko is an Ingalik word meaning "in the woods," but there is no general agreement as to its meaning or origin.

Since Nelson reserved the name Innoko for that part of the river above the entrance to Holikachuk Slough, it is possible, with the help of the few actual dates in his account, to reconstruct with some degree of certainty at least part of his route. After leaving Anvik, it is likely that Nelson and Fredericks ascended the Yukon to a point in the vicinity of the present village of Grayling, occupied by the former residents of Holikachuk, and then crossed over to the Innoko River in the vicinity of Holikachuk village. A winter trail in the area is still frequently used today. From that point the route can only be surmised. Nelson obviously ascended the Innoko, probably one of the few white men to do so since Petr Kolmakov had traversed the same territory from the opposite direction in 1838. It is doubtful, however, if he reached the headwater tributaries that Kolmakov had followed in going from the Kuskokwim drainage to that of the Yukon. The ret:irn journey probably followed much the same route since Nelson (1887, p. 16) mentions stopping again at Anvik, but the two travelers then proceeded down the Yukon and along the coast to St. Michael rather than by way of the Anvik River. This return route is of some importance in interpreting the information in his account because it means that he did not visit the lower Innoko at any time during these travels, though he refers to "the Shageluk" in his manuscript.

Edward Nelson left St. Michael in late June, 1881 aboard the Revenue steamer Corwin, serving as naturalist that summer on her northward voyage in search of the missing ship Jeannette. The Corwin visited the north coasts of Alaska as well as the Diomede Islands and St. Lawrence Island before returning to San Francisco in October (Nelson, 1887, p. 16). Nelson never did further work in Alaska, but spent the remainder of his long career in the southwest. 
California, Mexico, and in various administrative positions for the Bureau of Biological Survey, U.S. Department of Agriculture. His interest in Alaska and writings on Alaskan subjects continued, however, and in 1899 he published his major ethnographic work, "The Eskimo About Bering Strait," in which he carefully described the approximately 10,000 specimens collected in the course of his sledge and boat journeys from St. Michael. He retired from government service in 1929 and died on May 19, 1934 (Goldman, 1935, pp. 145-148; Lantis, 1954, pp. 9-10).

Nelson's sledge journey to the Yukon and upper Innoko in the winter of 1880 would have been a truly remarkable accomplishment for anyone else, but for this indefatigable man it was simply one of many such trips, all equally long and arduous. Although lacking in specific geographical information, Nelson's account of his journey is an important source for the ethnography of the area. It provides more information relevant to nineteenth century culture change than any other single source prior to the establishment of the Episcopal and Roman Catholic missions on the lower Yukon seven years later. Nelson $(1887$, p. 16) acknowledged that the emphasis of his trip was ethnological and he did not hesitate to supplement data obtained by personal observation with information provided by others. Through the co-operation of men like L. N. McQuesten, a pioneer Yukon trader who made frequent trips to St. Michael, Nelson derived his information concerning the Koyukon Indians of the Nulato area and the lower Tanana River (Sherwood, 1965, p. 94).

The most significant information in the notes on his journey, however, concerns the Ingalik Indians of the Anvik area. Cornelius Osgood, whose field work in the 1930's has provided most of the ethnographic information available concerning the Ingalik, believed, at the time of his field work, that these Athapaskan speakers comprised four units or subdivisions based on subtle linguistic and cultural differences. The first was the Anvik-Shageluk group, which centered around the village of Anvik on the Yukon and in settlements on the lower Innoko River, particularly Shageluk. The second group was identified with the now-abandoned village of Bonasila on the Yukon River approximately 22 miles above its confluence with the Innoko. A third group inhabited the villages of Holy Cross on the Yukon and Georgetown on the Kuskokwim. Osgood was less certain about the fourth subdivision, the McGrath group, occupying the drainage of the upper Kuskokwim (Osgood, 
1940 , p. 31). More recent research suggests that the Ingalik occupied only a small section of the Kuskokwim Valley above the village of Stony River as well as the drainages of the Swift and Tatlawiksuk rivers, Kuskokwim tributaries (Kraus, 1974).

Osgood's $(1940,1958,1959)$ exhaustive reconstructions of traditional Ingalik culture constitute the most comprehensive account of any northern Athapaskan peoples. He did not, however, concern himself with problems of culture change, although he was aware of the contributions of Glazunov and Zagoskin and summarized their data on the Ingalik and neighboring peoples well before information concerning the activities of these explorers was available in English (Osgood, 1940, pp. 35-50). From the standpoint of its usefulness for the study of Ingalik culture change, Nelson's account is important because his observations in the area took place after those of Zagoskin but before missions were established in 1887. From that time on, the published and unpublished writings of mission personnel form the basis for our understanding of the Ingalik reaction to the ever-increasing presence of Euro-Americans in their area in the late nineteenth and early twentieth centuries. It seems safe to say that between the departure of Zagoskin in 1844 and the arrival of Protestant and Roman Catholic missionaries 43 years later, Nelson and Hieromonk Illarion, the Russian Orthodox priest at Ikogmiut, were the only white men with an interest in observing and writing about the native peoples to visit the territory of the Ingalik.

Nelson's account also contains data on the inhabitants of the upper Innoko River whom he termed "Kolchan," a name which has had varied usage in the historical and anthropological literature on western Alaska. While at Anvik in January, 1834 Glazunov learned of a group of Indians called "Kyltchanes" who were said to inhabit the upper Kuskokwim River (VanStone, 1959, p. 43). Writing in 1839 Baron Ferdinand Petrovich von Wrangell, a former general manager of the Russian-American Company, noted that the Ahtna and Tanaina, Athapaskan groups in the Prince William Sound and Cook Inlet areas respectively, used the names "Kolchan" or "Goltsan" to refer to unspecified peoples in the interior. The names were said to mean "strangers" or "visitors" (Wrangell, 1970, pp. 8-9). Wrangell may have had access to Petr Kolmakov's unpublished journal since Zagoskin (1967, p. 300) noted that the explorer used a similar name to refer to the inhabitants of the upper Innoko and translated it as "nomads." Zagoskin himself applied the name 
"Goltsan" to the inhabitants of the upper Kuskokwim and believed that Kolmakov had been in error in extending its use to include the upper Innoko (Zagoskin, 1967, p. 243). Hieromonk Illarion referred to the Indians of the upper Kuskokwim and upper Innoko as "Kolchanes" and noted, at the time of a visit in May, 1866, that Holikachuk was "the first Kolchane village" (Oswalt, 1960, pp. 104, 109, 116-117).

Perhaps the most significant point to be derived from the above information is that the earliest travelers on the Innoko recognized a linguistic and cultural distinction between the inhabitants of the lower Innoko and the river above the settlement of Holikachuk. It is probable, however, that the name "Kolchan" and its many variations was simply a designation in several Athapaskan languages to identify people who lived inland from the speakers. Zagoskin (1967, p. 243) appears to have suspected as much when he noted that the name was "applied to all tribes of the interior by those living on the coast." Osgood (1940, pp. 31, 33), as we have noted, tentatively placed the upper Kuskokwim within Ingalik territory and he considered the upper Innoko to be within the area occupied by Koyukon Athapaskans. Holikachuk was thus a Koyukon village linguistically but because of frequent interaction with the Ingalik the inhabitants were culturally aligned with those people. This latter point is certainly correct, but the recent linguistic research of Kraus (1974) and his colleagues has resulted in the delineation of a new Athapaskan group which he calls Holikachuk and which includes the upper Innoko and a small section of the Yukon in the vicinity of the village of Grayling. As previously noted, the former inhabitants of the Innoko community now occupy this latter area. As for the upper Kuskokwim, Hosley (1968), on the basis of research in the McGrath region, designated the inhabitants of this area as an independent group of northern Athapaskans and gave them the traditional name of Kolchan. Kraus (1974) recognizes the linguistic distinctiveness of this area but prefers to designate it simply as Upper Kuskokwim.

The reader of Nelson's account who is primarily seeking information on the nature and quality of Ingalik life in the late nineteenth century just prior to the impact of missions and the influx of population resulting from the discovery of gold on the upper Yukon may be somewhat disappointed. More than half the manuscript is devoted to an account of myths, most of which are duplicated in other collections. and a description of festivals in the winter cycle of social and 
religious ceremonies which are described in greater detail by Osgood (1958, pp. 73-146). It was undoubtedly the weather-induced delay at Anvik which enabled Nelson to collect so much of these kinds of data. His eye-witness accounts of the ceremonies, however, are important primary source material. Combined with later descriptions by missionaries and Osgood's excellent ethnographic reconstructions, Nelson's data on ceremonies helps to make the ceremonial cycle of the Ingalik as well known as that of the adjacent Eskimos and better known than that of any other northern Athapaskan group.

Perhaps the most valuable information in Nelson's account concerns Indian-Eskimo relations, particularly Ingalik trade with the Eskimos of the Norton Sound area. Also valuable are his observations on resource utilization, and on changes in the resource base, and in hunting and trapping methods in response to the requirements of the fur trade. Particularly detailed is his discussion of the seasonal round of subsistence activities, a pattern that is difficult to determine in other nineteenth-century sources and even in Osgood. As a result, it is possible to ascertain the extent to which the Ingalik were involved in the fur trade in the 1880's. Nelson's information on death and burial customs usefully supplements data in Osgood, as does his reasonably detailed discussion of girls' puberty observances, courtship, and marriage.

One theme that runs through Nelson's account is his opinion that the Ingalik and also the "Kolchan" had borrowed a considerable body of customs and beliefs from the neighboring Eskimos. He saw this as a result of the long history of interaction between the three peoples and was convinced that the Ingalik and "Kolchan" were the borrowers because Eskimo culture traits were found only among Indians living in close proximity to Eskimo territory. More recent students of Athapaskan culture have been less willing to commit themselves on this subject although they readily acknowledge the obvious resemblances. In writing of the rich ceremonial life of the Ingalik, for example, Osgood (1959, p. 274) noted that his research failed to reveal satisfactory evidence of the borrowing of most of the ceremonies from the neighboring Eskimos. His informants believed the performances to be basically Athapaskan and he was unwilling to make a judgement either way in the matter. Whatever may have been the extent of Ingalik borrowing, it is clear that their way of life, as well as that of the Koyukon, Tanana, and Tanaina-other 
Athapaskans living in close proximity to the major waterways of western Alaska-resembled to a marked degree that of the riverine Eskimos of the same area. 


\section{PREFACE TO NELSON'S ACCOUNT}

Nelson's manuscript account of his travels on the Yukon and Innoko rivers in November and December, 1880 is undated and consists of 91 handwritten pages. It is deposited in the National Anthropological Archives, Smithsonian Institution, where it bears the designation BAE ms. no. 2109. The full title is "Manuscript on the 'Tinné' tribes of Alaska, information mainly from Anvik Indians, with some from Yukon Indians, and 'Kolchan' Indians from Innoko River." Although most of the information in this manuscript was never utilized in Nelson's many publications on Alaskan subjects, some material on birds and mammals was incorporated into his "Report Upon Natural History Collections made in Alaska. . . ." (1887).

In the following pages Nelson's manuscript is reproduced virtually complete with the exception of a very brief section consisting almost entirely of musical transcriptions. Also eliminated are the sketches of artifacts which the author interspersed throughout the text, but which are crudely drawn and do not supplement the written material in any way. An outline sketch-plan of an Indian house on the upper Innoko River is retained, however (fig. 4). Since Nelson made no attempt to divide his account into logical paragraphs, this has been done by the editor, necessitating some punctuation changes. Words appearing in brackets are those of the editor, while those in parentheses are part of the original manuscript. The few footnotes in the manuscript have been either eliminated or incorporated into the text. All editorial footnotes are numbered and placed at the end of Nelson's account. 


\section{E. W. NELSON'S NOTES ON INDIANS OF THE YUKON AND INNOKO RIVERS, ALASKA}

\section{Messenger or Barter Festival: Anvik Indians}

This festival is ordinarily one of the first ones held in winter. It generally takes place in November and seems to have no signification except the exchange of articles from one village to the other and the promotion of good fellowship between villages. This is a common festival with the Innuits from the Arctic Coast and Bering's Straits to Bristol Bay.

This festival is begun as follows: After winter sets in the people in a certain village find that they have more than they need of various articles of value such as deerskins, wooden dishes, or other things and they lack certain other desirable articles. They decide to hold a barter festival and invite the people of the neighboring village.

Nearly everyone in the village has some article he wishes to exchange and in consequence he becomes one of the feast givers. When a large supply of food is prepared and all is ready the two head men of the villages prepare two slender batons which they paint with bright colors and then these are given to two young men who are instructed to give the batons to the two head men in the village decided upon by the feast-givers.

The messengers arrive at their destination and deliver their batons and tell who sent them. Then the messengers recite to the assembled villagers the things most desired by the feast makers and the articles that will be given out by them at the festival. Each of the messengers is given some new article of clothing and they are treated as guests of honor during their stay.

The villagers make ready and, placing their articles on sledges, start for the feast. When one day's journey from the village giving the feast, one of the messengers hurries on ahead to notify his people. The next day the other messenger runs on ahead and notifies the people of the approach of the guests. 
The guests are received with great hospitality and are apportioned among the different householders. The last messenger who leaves the approaching guests is told by each of the guests what he particularly desires such as an article of clothing or other thing.

Soon after the arrival of the guests all gather in the sweat house and the women bring in a bountiful supply of food. When everyone has feasted to his content each man brings in some article asked for by one of the guests and gives it to him and if it is an article of clothing, he helps the guest put it on. Then the hosts unite in a dance and song of welcome which occupies the first evening.

The second evening the guests bring in and distribute their presents after which they dance and sing a song addressed to their hosts.

On the third evening the hosts bring in and distribute fresh presents and this is followed by a general dance in which both sides take part and the festival is ended.

Frequently more than one village is invited to take part in one of these festivals. The next year some of the guests at this festival will make another one and invite their hosts of the year before. In this way a considerable exchange of goods is brought about. ${ }^{1}$

\section{Festival to the Dead}

On December 10,1880, during one of my sledge journeys, I came to a small Indian village near the head of the Innoko River. There I found nearly all of the able-bodied men of the Kol-chan Indians assembled by invitation to witness and take part in a feast given in honor of the dead.

The principal feast makers were a young man and an old man, but the entire village took a more or less active part in it. The shades to be honored in chief, however, were relatives of the two men named, and, in a general way, the shades of other village dead whose relatives took part.

I arrived after the festival began and from that time on kept note of all the ceremonies. The two principals, I was told, sang a song prepared for this occasion in the morning and the evening before the day set for the festival to begin.

On the evening of my arrival I noticed some excitement about the sweat house and went in. All of the women came in and sat opposite 
the doorway. In the middle of the room in a row facing the door sat four old men. These men sang several songs, each one ending with a low but high pitched "hoo, hoo, hoo." In about half an hour some young men held up two blankets so as to conceal the door and all of that side of the room. Directly after this two women and five men came in and ranged themselves along the wall behind the blankets, one woman at each end of the line, and the blankets were taken away.

One man wore the tail feathers of a white owl in a fillet so arranged that the feathers stood up straight from the forehead. The other men each had a similar fillet in which were the feathers of a gyr-falcon or some other bird of prey.

Three of the men each had a large downy feather fastened in some way to the tips of their noses. The men all wore new blouses of fancy ticking. The women had one or two black-tipped wing feathers of a seagull in their hair and wore blouses of bright colored calico, also new. In her right hand each woman held a slender rod about $3 \mathrm{ft}$. long and tipped with a large, downy white feather.

The old men at once resumed their song, beating time with slender sticks on a smooth, round log that lay before them. The new comers began a slow dance in time to the song. The movements of the men consisted of a mere jogging of the weight first on one leg and then on the other, with a corresponding heave of the shoulders, all without moving the feet from their place on the floor.

The women made a forward and backward motion of the body at the hips accompanied by a light bending of the knees each time and a slight twisting or rotary motion of the body as the last, or recovery, movement. The women kept their wands in constant slight motion in time to the song. After the dance had gone on for some time the singers uttered the final "hoo-hoo-hoo" and stopped. The dancers stopped at once and turned with their faces to the wall and stood thus until the song was taken up again when they would wheel about and begin once more. This was repeated several times. All of the dancers wore mittens and every now and then during the dance they would draw out a pinch of fine white down in one hand and blow it toward the middle of the room where the singers sat. When this was finished everyone went to bed.

At 2:00 A.M., the next morning, I was awakened by the singing of the old men on the roof of the sweat house. The song ceased and the 
hewn end of a stick was pushed a little way into the smoke hole and then came a long song. After it was finished the end of the stick was pushed slowly down until a young man inside caught hold of it and drew it down until the end rested on the floor. It was a slender spruce pole, unpeeled except a little bit at the butt. All along its sides were stuck long, downy white feathers.

After singing another song the men on the outside came in. The chief shaman of the village then started a song which was taken up by the other old men and followed by the seven dancers of the evening before. The latter wore old clothing and gathered in a ring about the spruce pole and began to dance as before.

These dancers were soon joined by another who brought a wolfskin over his head. He circled once around and touched the pole and then one of the seven dancers took the wolfskin and hung it on the wall of the room. In this way the dance went on for hours, some new man, or woman, bringing in a contribution every 15 or $20 \mathrm{~min}$. In the end a varied lot of stuff hung along the wall consisting of wolf, wolverine, and other skins, calico, drilling, tobacco, etc., etc. There averaged from 8 to 12 dancers and the unvarying song was kept up with all the power of their lungs.

The old men and dancers did most of the singing as the others very rarely joined in. The song was an endless repetition of the syllables "oh-hee-ha; hee-ha; hee-ha-hay" varied by "ha-ha-hay; hee-ha; hee-hee-ha." The dancers threw the upper part of the body back and forth violently and stamped time vigorously on the floor with one foot. The dancers streamed with perspiration and as fast as one became exhausted and dropped out of line his, or her, place was taken by a newcomer.

The dance ended at 10:00 A.M. and food was brought in. After some fragments of food from each vessel and some water from the watertub had been cast upon the floor as an offering to the dead, the food was handed out by the women and all ate heartily. Then the seven original dancers, who were namesakes of the dead in whose honor the feast was given, were called out in the middle of the room and fine new clothing put upon all of them and, the articles hanging on the wall having been distributed generally, the festival was at an end.

I was told that two other similar festivals are to be given by Kolchan villages right away. During the continuance of this festival the 
use of sharp tools and instruments was forbidden in the village fearing to injure the shades. ${ }^{2}$

\section{Festival of the Dressing of the Dead: Anvik Indians}

Every year the Indians of Anvik and the Shageluk celebrate this feast during the December moon. The people from neighboring villages are notified of the time when this festival will be held. No special messenger is sent but anyone who goes to an outside village is commissioned to extend the invitation. As the villages usually hold this feast in turn, a man can attend several of them if he desires.

The first evening of the feast after the guests have arrived, the namesakes and representatives of the dead, in whose honor the feast is given, enter the sweat house and are seated in a row on new straw mats in the place of honor, opposite the entrance. The feast-makers now bring in a large supply of frozen fish and distribute it among the people. The namesakes are given also boiled fish in fine new wooden trays or dishes. Each feast-maker casts an offering of the food upon the floor for the shades before he distributes the food and also before he gives food to the namesakes. At the same time everything given the namesake is supposed to insure the direct benefit of the shade so represented.

The second evening a large birch tray full of decayed and frozen fish roe is distributed and the namesakes are given trays full of the roe and other delicacies.

Every evening during the continuance of this festival, after the distribution of food, the villagers join in dancing in time with songs and drums, the latter like those used by the neighboring Innuits. Early on the morning of the third day the feast-makers bring in a large quantity of mixed chewed reindeer [caribou] fat and berries, as throughout this festival offerings are cast to the shades and the choicest bits are given to the namesakes.

Each feast-maker now goes out and brings in a bag of new clothing prepared for this occasion. A feast-maker may have but one dead person to honor in which case he, or she, has but one namesake to provide for, but it frequently happens that one feast-giver will have several relatives to remember in which case he has a namesake for each one of them and provides clothing for all alike.

The feast-makers then take out their clothing and help the namesakes put it on, including fur coat (parkie), breeches, boots, and 
gloves. When all are dressed a large supply of dried salmon is brought in and distributed after which it is carried out by the recipients. The namesakes then rise, take their mats under their arms and carry out their food trays, taking home all that has been given to them.

The day is passed in singing and dancing. Early on the fourth morning everyone rises and, while sitting down in the sweat house, stamp heavily on the floor four times. Then they go out and into each house in succession where they sit down and stamp four times.

This signal sends the shades back to the land of the dead and ends the feast. The old man who gave me the foregoing details also explained to me the following points. The shade is supposed to be his namesake during this festival. This feast is given the second winter after a person dies, and as often thereafter as the relatives can afford it. Several persons always unite in giving one of these feasts in order to render it more imposing in the matter of gifts, etc. The feast-givers are bound to provide an abundant supply of food for everyone besides the usual gifts. These feasts are given for near relatives such as the parents, wife, children, brother or sister, nephew or niece.

During the continuance of this feast no one is permitted to cut wood with an axe or knife, no sewing is allowed and, in fact, no pointed or edged tool is used about the village. Firewood is broken by striking one stick across another unless it was prepared before the feast began. The reason for this is that the shades of the dead are all about the place at this time, though invisible, and a person using a sharp instrument might cut one of them by accident and make it angry, and so cause it to revenge itself upon the villagers by bringing them sickness or some other evil.

This festival is the same as the one described on the Innoko River except that the Anvik people show the influence of their Innuit neighbors in many of the details and observances. ${ }^{3}$

\section{Bladder Festival}

This festival is borrowed from the Innuits and is found among the Indians only to the head of Shageluk Island on the Yukon. The following details were given me by some old men at Anvik.

The feast is held there sometime before the January moon each year. Guests are not invited nor expected as the feast is for the 
special interest of the members of each community in itself. At the same time chance guests are entertained hospitably. I wish it understood that the following notes are but an outline of this festival and do not purport to give the full details.

The sweat house is ornamented [with] newly split strips of wood 2 or $3 \mathrm{in}$. wide and from 3 to $4 \mathrm{ft}$. long and gaily marked by bands of bright colored paints. These strips are fastened into crevices botween the logs near the roof, and are ranged all along the front and back ends of the room. At the outer end of each strip is the carved wooden model of a reindeer, bear, wolf, fox, rabbit, grouse, or other animal or bird; or, they bear the model of a gun or other hunting implement. Upon the sides of the room are fastened six bundles of rosinweed stalks, three bundles on each side. These bundles are fastened to the wall by wooden pegs and are about an equal height from the floor.

Just below the wooden strips at the back end of the room and extending from side to side are two or more strong rawhide cords. From these cords hang suspended bunches of inflated bladders of reindeer, moose, bears, otters, and other animals taken by the hunters of the village during the past year. Each bladder is marked by a line drawn around it with white paint.

Leaning against the wall upon each side of the usual central lamp at the back of the room are two large boards banded with red and black paint with white paint in spots between the bands. Each of these boards is made with four large scallops on each side and, in the middle of each scallop, is inserted the quill feather of a goose and a bunch of down is fastened at the top of the board.

Between these boards and under the bladders is an upright post fastened in the floor, with a fork at the upper end, and about $5 \mathrm{ft}$. high. This post is painted and ornamented with quill feathers just like the boards.

All of these things are put in place and kept there for 10 days and then the bladders are brought in and hung up and the festival begins.

The evening that the bladders are hung two men wearing black masks come in and dance while all the people unite in a song. This is repeated the three following evenings. On the fifth evening all of the people whose places are on the bench under the bladders have small, newly-made wands about a yard long, banded with red paint and 
tipped with a tuft of reindeer hair. These wands are moved slowly up and down in time with a special song for that night.

On the sixth evening the two black-masked men come in and sit one on each side of the lamp at the back end of the room. Then each one begins beating time with a stick on a small board he has made for the purpose. Soon after this a long line of men come filing in, all wearing masks of various kinds. They form a line along the front of the room opposite the bladders and execute an ordinary posturing dance.

This is repeated on the seventh and eighth evenings. On the ninth evening the men place their beds in a circle in the middle of the room and unite in singing while the women are ranged about the walls. The two men come in dressed in fine new masks and clothes and one of them dressed as a woman. This couple dance in time to the song throughout the night.

When they become tired they go out for a short time and then return and go on with the dance. The singers go steadily on with short intervals during all the night.

Early on the morning of the tenth day the cover is taken off the smoke hole in the roof and a crowd of masked faces look down into the room and cry "Where is our axe? We have lost our axe. Here is a hole and perhaps it has fallen in here." The dancer dressed in man's clothes now comes forward and hammers on the floor with an axe made in the style of the old stone axes. At this the maskers on the roof cry out "There it is, there is our axe. Throw it back to us." Then they throw down a deerskin saying "This is to pay for it, now throw it back." The man throws the axe up through the hole and the maskers unite in a dance and song of thanks for the return of the axe.

Then the people inside pull down all of the ornamented sticks from the walls and after breaking them cast them into the fireplace in the middle of the room. Half of each bundle of rosinweed is also thrown there. The maskers from the roof now come in and after circling around the fireplace singing and dancing they cast their masks upon the pile. The rosinweeds not thrown on the pile are now lighted and waved about until the room is filled with the aromatic smoke and the people all join in a song. After this the masks are taken up and carried out and hung in storehouses or trees until needed the next year. Each man now takes the bundle of bladders belonging to him 
and carries them out into the woods where he breaks and leaves them if they are bladders of land animals. The bladders of otters or other water animals are broken and put into the water through a hole in the ice.

This ends the festival. The next morning the young men toss one another on a large seal skin and on the second morning they have foot races and other games. During the 10 days while the bladders hang in the sweat house no hunting or trapping is permitted and it is forbidden to bring a fox or a rabbit into the sweat house. During this time whenever anyone brings food or water into the house they take it first to a bundle of rosinweeds that is placed on a short stick just back of the lamp in the back of the room-the forked stick described [p. 23] -and sprinkle a little of the water on them or drop a little of the food on the floor in front of them saying, "I give you this." "And you also," he says turning and throwing a little of the food or water up to the bladders overhead. If a man has killed no animals during the year so that he has no bladders to hang up, he takes a small bundle of rosinweeds and hangs it up with the bladders and observes all the rites to it as though it was a bladder.

As with the Innuits, this festival is a species of harvest-home. The bladder is supposed to contain the shade of the animal it was taken from and when the bladder is taken out and opened in the woods, or at the waterhold, the shade escapes and hurries off to enter another one of its kind. By the songs of thanks that are sung to the bladders with the dances and votive offerings of food and water the hunters count upon pleasing the shade so that it will return to him again in another of its kind and thus give him success in the chase.

All of this is taken directly from the Innuits with some Indian observances added. ${ }^{4}$

Anvik Doll Festival: Given in January Moon Each Year. As Described by Old Men at Anvik

Two large wooden hoops are made to extend around the inside of the sweat house. One of these is suspended a little below the other, and both hang about midway between the roof and floor. From the smoke-hole in the roof a large number of slender rods extend down and are fastened at intervals around the upper hoop.

The hoops and these rods are banded with red paint and small tufts of downy, white feathers are fastened to them at intervals. At 
the back of the room directly opposite the entrance way are fixed two slender posts about $5 \mathrm{ft}$. long, upon the upper end of which is placed at right angles a small board. On one of these boards are placed in a sitting posture two small wooden dolls completely dressed as a man and a woman. Beside the man lay the models of a threepronged bird spear on one side and a paddle on the other. Beside the woman is a model of a paddle. On top of the post to the right is the image of an old man fully dressed and alone with a paddle standing by him. The posts are banded with red paint. For two days these images are kept thus while the people of the village abstain from all work and are very careful to make as little noise as possible in the sweat house. The images are supposed to be very sharp-eared and to dislike a loud noise so no one is permitted to drop anything, stamp their feet or talk in a loud tone in the house. On each of the two nights mentioned certain songs are sung, made up of a series of unmeaning syllables supposed to be very pleasing to the images.

On the third evening five men come in, each bringing the small wooden images of the birds, fishes, and animals they hunt for food and clothing. These images are tied into five bundles and are hung from the slender rods near the roof, nothing being hung to the wooden rings. Then these men go out and return with dried fish which they distribute among the people.

On the evening of the fourth day all of the people of the village gather in the sweat house. Then each of the older men in the village takes a girl or young woman by the arm with his left hand and carries an arrow in his right hand. Each of the young men and large boys then take the older women in the same way and all march around the room singing a song. When this is done all disperse every pair so formed becoming husband and wife for that night.

The next, or fifth, day the men all go out and each one brings a load of wood to the door of the house where his temporary wife lives.

Then the rods are taken down from the roof and a fire is built to warm the sweat house and after this is done the rods are replaced. Then the women come in bringing food, each woman serving her companion of the night before and, at the same time, making him a present of some article of dress, such as a pair of gloves. In the evening the women dance by themselves.

On the sixth day, very early in the morning, all of the rods and hoops are broken up and cast into the fireplace. The images are taken down and packed carefully in fine wood shavings, with a piece 
of dried salmon and deer [caribou] fat in each package, and a piece of white birch bark is wrapped about all. The man and woman are packed together and the man who was alone on the board is packed by himself. The two packages are then taken out and hung up in a tree in some retired spot well sheltered from the weather. The broken rods and rings are then thrown out of the sweat house and the festival is over. No one must go near the images hung in the trees except when taking them to or from the feast. If anyone should touch them at any other time he would surely be sick and die.

When the time comes the next year for the feast, the oldest shaman or head man of the village goes out and brings them in. Then they are opened in the sweat house and on the inside close to the images are found little tufts of hair, feathers, or bones of all the animals, birds, and fishes that will be taken during the coming year.

If the sign of any animal, bird, or fish is absent, it is a sign that this kind will be scarce during that year. If a piece of charcoal is found it denotes that some of the villagers will die. These images represent three people who live in the sky in a fine land where there is an abundance of deer [caribou] and all other game and from which the earth is supplied. No one but the shamans can get there from the earth.

If the three people represented by the images are well treated, they will help the people and make plenty of game, but, if they become angry at anyone, he will become ill and die. The shamans sometimes go to them to get their aid.

This festival is observed from near Mission to the upper end of Shageluk Island. ${ }^{5}$

\section{Anvik Mask Festival: From Old Men at Anvik}

This is a festival given during the February moon and intended as a diversion.

The men of the village compose some new songs which each one sings alone in the sweat house. Then they teach the songs to the others. When the songs have been learned the men all go out and get wood suitable for a mask. Each one makes himself a mask, imitating the head of some animal or some imaginary shape, such as a grotesque human face. When these are ready two small masks are made and gaily decorated with paint and feathers. These are given to two young men and they are sent out to invite neighboring villagers. 
When near a village these men put on their masks and wait until evening. When it gets a little dark they enter the sweat house with a bound and cry out "Shi, shi, ko-ga-hi" or, "hush, hush, men come." They repeat this several times and then dance for a few minutes, after which they remove their masks and are made welcome. They tell the object of their visit and are given presents of new gloves, boots, etc. by the villagers. Accompanied by all the people they start back the next day.

When they are near their own village the messengers run ahead and dancing in front of their sweat house door, cry out as before, "Shi, shi, ko-ga-hi," while the guests arrive and go into the house and are given food.

In the evening the first part of the entertainment consists of a dance by three men wearing enormous masks. After this is ended all of the men go to some grass mats near the door and raise them showing a pile of masks concealed there. Each man in succession puts on his mask and dances singly while the rest of the villagers sing the song composed by him. When five songs have been sung and the five dances completed, all of the villagers go out and bring in presents of fish, oil, deerskins [caribou skins], etc., etc. which they distribute among the guests. Then five more songs and dances are given and more presents distributed, and so on until morning and the festival is at an end. ${ }^{6}$

\section{Burial Customs of Yukon Indians}

When an Anvik Indian dies, either man or woman, the body is dressed in a full suit of new clothes and then placed in a sitting position on the floor, in the middle of the house. The feet are drawn back until the heels rest against the thighs and the knees are drawn up near the chin. The arms are placed so to embrace the knees and the body is bound in this position by means of cords. Three stakes are then driven into the ground; one at the back of the body to which the latter is tied, and one at each elbow. When the body is in position, [a] black band is drawn with charcoal across the eyes ending on each temple.

The body is usually kept in this position for two days while the friends and relatives sing or dance about it in a circle. If the deceased was a person of importance, or was much liked, the body is taken to the sweat house and there put in position with stakes and is kept there for four days while the villagers sing and dance about it both 
day and night. A portion of this time the women fast, but the men do not. ${ }^{7}$

At the end of two or four days the body is taken from the stakes and laid out on one side and wrapped in grass mats and bound with rawhide cords. The body is then hoisted out through the smoke hole in the roof. ${ }^{8}$

If the deceased has many relatives or was a great favorite, a scaffold is built on some point outside the village and upon this the body is laid for a month. During this period every morning at dawn the nearest female relative if the deceased was a male, or male relative in the case of a female, goes to the spot and builds a fire close by the platform. Into this fire each morning would be cast an offering of food and water, and then the mourner would sit and weep and mourn for the departed. At the end of this period the body is taken down from the scaffold and the mats are removed from about it. ${ }^{9}$

The grave box is provided with a deerskin [caribou skin] bed on which the body is placed, lying drawn up and on one side as described. If it is a man, his woodworking knife is placed by him and, if a woman, her fish knife and work bag, and the box is then closed.

Meanwhile, a larger grave box has been built on four posts above the ground and a layer of 4 or $5 \mathrm{in}$. of earth placed in the bottom. On this the box containing the body is placed so that there is a space of several inches all around between it and the outer box. This space is filled in with earth and several inches of earth on top and over all is a roof of bark or rude boards..$^{10}$

The boxes are made of rude hewn planks fastened together by wooden pegs. The graves at Anvik were located, some of them on the opposite bank of the river from the village, on high ground above all danger from high water, and some of them on top of a small bluff below the village. ${ }^{11}$

A grave box at the latter place was about $3 \frac{1}{2}$ by $4 \mathrm{ft}$. horizontal measurement and $3 \mathrm{ft}$. deep. It was strongly made of planks. The bottom was $1 \mathrm{ft}$. above the ground. The box was supported by a post at each corner, these posts extending $3 \mathrm{ft}$. above the top of the box. Two feet over the top of the box was a flat roof of split logs covered with birch bark. As a rule, these boxes and posts are made with a rude symmetry that is creditable to the skill of the maker. ${ }^{12}$

Below Anvik a few miles is a large graveyard containing many grave boxes in front of each of which is the figure of a human head 
and body on a post about $4 \mathrm{ft}$. high. I was passing this place on a forced march and had no chance for a careful examination as I expected to return there later, but failed to get the opportunity. These images are very well made and all of the newer ones had on skirts of drilling or some other cloth. Most of them were sheltered from the weather by an A-shaped roof. I was informed that these figures represent the dead in boxes behind them, and the relatives place new clothing upon them and make food offerings at the period of the festivals to the dead. At the end of a year from a person's death, the relatives go to the grave and open the box to see if the clothing needs replacing. If it is in good preservation, the box is reclosed and it is optional whether they visit it again or not. If the clothing is decayed, then new articles are spread over the body and the box is closed again. ${ }^{13}$

In case of its being a shaman, the relatives place the remains in a new box and put in new bedding and clothing at the end of the third year from his death. Then, at long intervals, as this box decays, it is replaced by new ones. When the boxes are changed thus the shaman is supposed to rest easier, for he is thought to lie as though sleeping. With common people this makes no difference. ${ }^{14}$

The bodies of bad people or witches and wicked shamans are burned after death and other bodies are sometimes burned at the expiration of two or three years if they continue to smell very offensively. In the latter case the bones are gathered up and placed inside of new clothing and returned to the box..$^{15}$

Before one of the great, or "ten year" festivals to the dead, new clothing is put into the grave boxes of those to be honored at the feast. This is done in the last part of the summer preceding the festival. ${ }^{16}$

When a boy dies his father tears off his upper garments and rushes out and throws himself naked into the snow if it is winter; and, if summer, he rushes into the water and has to be dragged out by his friends. The mother, sister, brother, or wife also rend their clothing, tear their hair, and roll in the snow or rush into the water all the time weeping and howling mournfully. If the other relatives were fond of the deceased, they also weep and tear out their hair and rend their garments.

If a woman's husband dies, she tears off her clothing, cuts or scratches her thighs and breasts until they bleed, and casts herself upon the ground with wild wailings and tears. If her child dies, she 
does much the same but with less fervor and only scratches with her finger nails. These violent demonstrations occur both at the time of the death and also when the body is taken out for burial.

But the shamans teach the people that they must not weep too long for a dead person, as too many tears will render the clothing of the shade quite wet and uncomfortable, but just tears enough are very pleasant to him. All the near female relatives of the deceased cut their hair close and hang the cut hair in trees. Both male and female relatives remove the fur trimmed collars of their fur hoods and must do without them for a year in a sign of mourning. ${ }^{17}$

At a summer village below Anvik I saw two little bags hanging from trees and full of human hair from some women mourning their dead. On another tree, about $15 \mathrm{ft}$. from the ground, hung, securely tied, the long abundant hair of another woman. Her little child had died here the previous spring, my guide explained.

At the mouth of the Innoko River is a large Indian graveyard of which three accompanying photographs are views, taken December 7,1880 (see fig. 3). There were about 30 graves there at the time of my visit and many had been washed away by spring freshets. In front of each of these graves were long peeled poles placed upright in the ground and about $10 \mathrm{ft}$. from the ground on most of them was fastened a rifle placed cross-wise. ${ }^{18}$

These grave boxes are made of hewn slabs supported and roofed as the box described at Anvik. On boxes containing men were usually painted in black the figures of three or four reindeer [caribou]. ${ }^{19}$ On the side of one boy's grave the same figures were marked and the box was studded with brass buttons. On the boxes containing women were painted in black the figures of the old, pointed style hunting shirt and also the figures of the present style adapted from the Innuits. Hanging under the roof of one woman's grave was her head belt and hair ornaments. Upon a post, and sheltered from the weather by a double sloping roof, was a good pair of snowshoes. Sheltered in the same way and placed before a man's grave was a bow and a quiver full of arrows. Drawn completely around some of the grave boxes was a width of drilling or ticking and several small strips of cloths fluttered from the tops of the poles. This cloth about the grave box is renewed on each of the two years following the death. $^{20}$ 


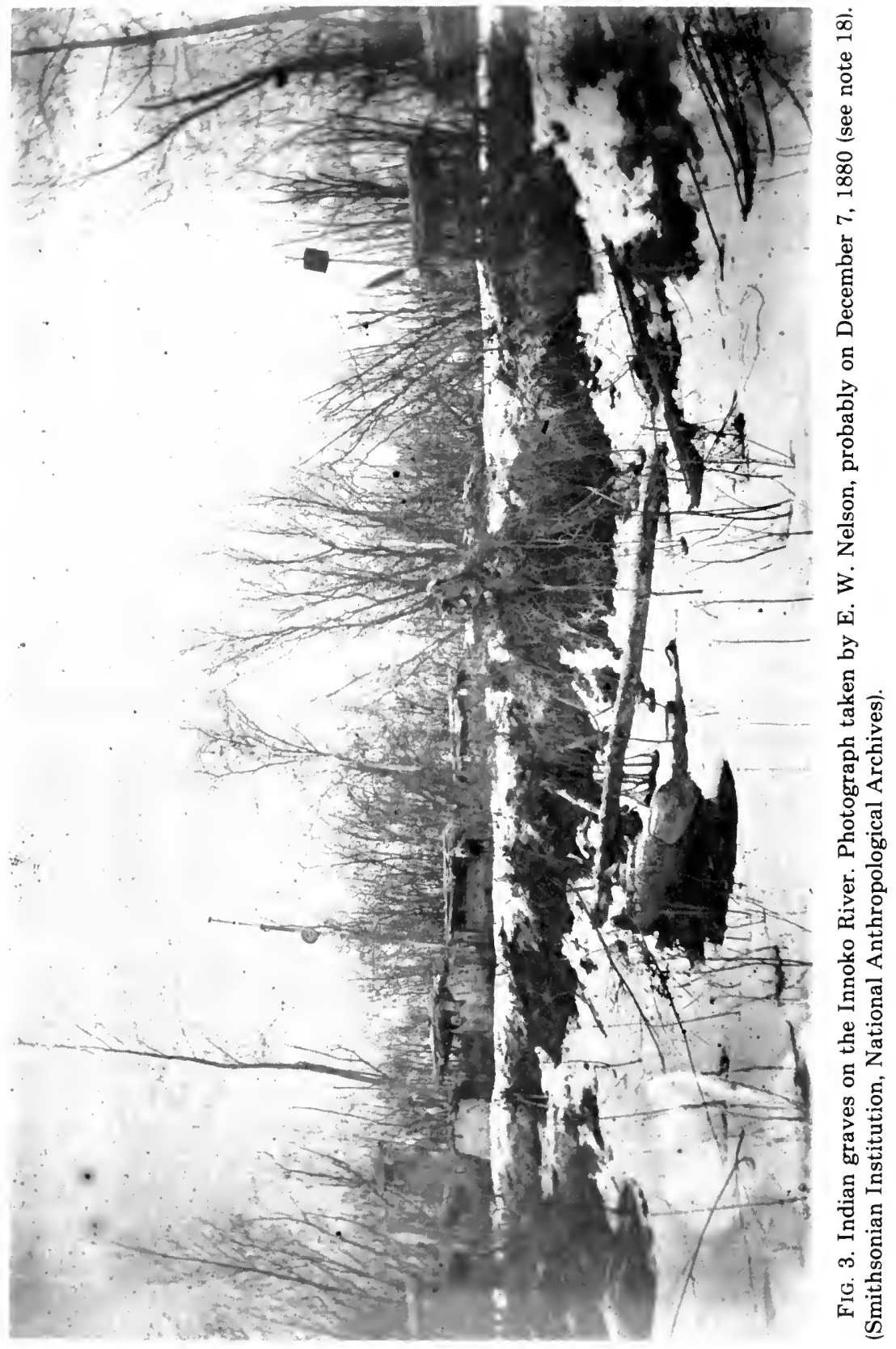


Here as at Anvik the body is buried in new clothing and new clothing is put in the grave box at the end of the first year. If nothing but bones remain when new clothing is put into the box at any time, they are gathered up and placed inside the clothing. The same care is taken of a shaman's body, but, in addition, at the end of the third year the shaman's bones are placed in new clothing and the old grave box is replaced by a new one.

At this place I saw a fine grave box painted red and ornamented by figures of a deer, an otter, and a sealskin oil bag, in black. This box rests on two logs of wood to keep it above the ground and measures $3 \frac{1 / 2}{\mathrm{ft}}$. long by $15 \mathrm{in}$. square at the ends. This I was told by the Indians contained the bones of a shaman and was his second grave box.

Standing quite by itself and close to the village, at this point, was a finely ornamented grave box containing the body of a noted shaman. The Indians placed it there fearing that he would be angry if put among the others. When they pass his grave the people place upon it small offerings of dried fish, tobacco, or other things and ask for good weather or successful hunt or other favors of a like kind. All of the newer grave boxes at this place were painted red..$^{21}$

On my way up the Innoko River we came to a deserted village about 30 miles from the nearest people. I was surprised to be met there by a dignified-looking old Indian whose figure was still straight, although he was evidently old and feeble. The Indians who were with me said that his wife, who had been a shaman, had died here about a year before and that he had stayed there by himself ever since making continual offerings to her shade and performing such simple rites as he thought would please her in the land of the dead. He had some children living on Shageluk Island who wished him to live with them, but he would not leave this place. He seemed very quiet and said little to my Indians though he sat with us and appeared glad of our company until we went to bed. The next morning I gave him some tea and bread from our scanty store at which he expressed his thanks and stood watching as we passed up the river and out of his sight. ${ }^{22}$

One old man at Anvik told me that people who die a violent death and murderers go up to a land in the sky. Also that people who are drowned and their bodies lost go to a bad uncomfortable place in the other world. I had nothing from anyone else on these points, perhaps through lack of inquiry, so I give it for what it is worth. ${ }^{23}$ 


\section{Hunting}

The moose is the largest game animal of this region and is now very scarce. The Indians of the Yukon Valley go out hunting them on showshoes when the snow is very deep or there is a hard crust through which the moose will break at every step. The hunter is stripped to the least possible amount of clothing and carries a light gun (formerly a lance, or bow and arrows). The moose is overtaken and shot and the hunter returns to camp while women who have followed the trail cut up the game and drag it home on sledges.

Reindeer [caribou] are stalked at all seasons and in summer the moose is sometimes killed when crossing the Yukon.

The Indians are now all provided with muzzle-loading rifles and can get ammunition [at] any trading station and, as a consequence, game is being destroyed very rapidly. To help along this extermination, quite a number of breech-loading rifles with ammunition are getting into their hands along the lower Yukon. These guns come mainly from the Malemiuts who obtain them from trading vessels on the Arctic coast.

On the Yukon the hunters commonly carry a bow and arrows, with their gun, to use on rabbits, muskrats, and other game not considered worth a charge of powder. ${ }^{24}$

Trapping begins on the lower Yukon the last of October or first of November, the exact time depending on the date of the first hard frost that covers the pools and small streams with ice and renders the ground firm. Then traps are put out for foxes, lynxes, marten, mink, land otter, beaver, and muskrats. The season runs till the last of December after which very little is done until the end of February owing to the intense cold and the short days. The last of February the traps are reset and the season runs until the glaring March and April sun reflected from the snow bleaches and renders worthless the fur of the foxes, marten, and mink. The sun at this time bleaches the fur to a rusty reddish hue and renders the long hairs so brittle that the skins have little or no value.

In spring when the ice breaks on the Yukon and all the low land is flooded, the Indians of the lower Yukon go out in canoes and hunt beaver, land otter, and muskrats. Bow and arrows or the rifle are used for this purpose.

On December 9, 1880 I found a couple of men in the sweat house at an Innoko River village, hard at work skinning four land otters 
they had taken that day. One of the men had taken three of them. These had been taken by being tracked to their hole in a snow bank by the riverside and then clubbed to death as they were driven out. The otter is much given to traveling from one stream to another, or up and down the stream he frequents. In winter he plunges through the snow by short leaps and is easily run down and killed by a hunter on snowshoes. The Indians take up a fresh trail and either overtake and kill the animal or drive it into its hole where it is forced to come out and is killed. Sometimes a number of them are taken from a single hole in this manner. They are also trapped by placing steel traps set at the bottom of their holes leading under the ice on the bank of a stream. The marten is also tracked until treed and is shot by the Anvik and other Yukon Indians.

Beavers are taken by trapping or by being killed in their houses in winter, as well as being shot from canoes in spring. Reindeer [caribou] are snared by means of a strong noose set among bushes where they frequent so that they will be caught by the neck or horns. For lynxes a large pile of brush is made in a secluded spot and in a small open space directly under the middle of the pile is placed the bait. Then two or three openings are made from the outside through the brush to this central space. In these openings are set nooses of rawhide or sinew cord. The lynx tries to thrust its head into one of these openings and is caught and strangled. Snares are set in run-ways for white rabbits and ptarmigan are snared by nooses set among the bushes where they resort regularly, or little fences of brush are made with openings at intervals guarded by snares. ${ }^{25}$

The most common method of trapping is by means of the deadfall. This is made after the well-known plan: a little enclosure about the bait, made by driving stakes in the ground, and across the front a couple of small logs, the upper one moving up and down and held in place ready to drop across the neck of the animal when it puts its head in and touches the bait and so looses the trigger. In this way are taken martens, lynxes, mink, foxes, wolverines, and sometimes bears. This is the main method by which the great supply of furs is annually taken by the northern Indians. ${ }^{26}$

The Yukon Indians start out in fall and make a circuit, sometimes as much as 40 miles long, over which they place these deadfalls at intervals. This route would require two days to visit and is gone over about once a week during the season. Every hunter has a certain district allotted him in which no one else is permitted to trap. 
These districts are usually prized as so much property and a son inherits his father's right to it. Any infringement of another's rights there would give rise to jealousy and feuds. ${ }^{27}$

During the trapping season it is the orthodox way to clean, stretch, and leave the skins taken in the woods until the season is ended, but at present this is rarely done. Above Nulato the Indians hunt bears in spring by tracking them to their holes, when warm weather first brings them out, and then fastening logs across the entrance. When this is done the bear is stirred up and when he thrusts his head out he is shot. ${ }^{28}$

\section{Fishing}

The king salmon is the most important fish obtained by the Yukon Indians. A common method of its capture with all of the Yukon Indians from Anvik to Fort Yukon is by means of a dip net. The fisherman goes out in his canoe and drifts down with the current holding his net down in the water. As soon as an ascending salmon is caught he is lifted out, killed, and placed in the canoe and the operation is repeated. By the last half of June the king salmon are running at Anvik and the people then have out their large wicker fish traps. These are set at the outer end of a long fence of stakes set in the water, extending out from shore. ${ }^{29}$

From the last of June until after the middle of August the various species of salmon continue to run and everyone is busy. The men attend to the fish traps and the women cut up and hang the fish to dry on long frameworks of poles. In this way the winter food supply is insured and a failure of the salmon run means famine to the Yukon Indians. ${ }^{30}$

The good sites for fish traps are the property of the various hunters in the adjacent village among the Anvik Indians in the same way that the trapping ground is laid off and held as a personal right. ${ }^{31}$ Every man with a family either has a fish trap of his own or joins with another in the ownership of one. In winter these traps are kept set constantly. On small streams the trap is placed in the middle of the river with a fence leading to the shore on each side.

On November 20, 1880 I found a trap of this kind set in the Anvik River. The mouth of the trap faced downstream. We stopped and raised the trap and found about $20 \mathrm{lbs}$. of beautifully colored grayling, whitefish, and salmon trout. 
During high water these wicker traps are taken up and gill nets set. The care of the wicker traps is considered the business of the men. The gill nets are also set by men in the Yukon as soon as the ice goes in spring and are kept out until the water falls and the traps are put up. The gill net fishing for whitefish, grayling, and pickerel in the smaller streams is mainly attended to by the women. ${ }^{32}$

Various species of whitefish run in the Yukon for about a month in fall and are taken in large numbers. This is usually in October and the first of November.

As soon as the river freezes over, the loche runs for the month and is taken in the traps in large numbers. ${ }^{33}$

The last of November each year the lampreys run up the Yukon by Anvik in great numbers. The Indians have a series of holes in the ice ready for them and a sharp watch is kept. The moment they are seen in the lowest hole everyone rushes out upon the ice with scoop nets or a stick with two cross-bars at the end and as the lampreys pass one of the holes made in the ice they are scooped and thrown out in great numbers. Then everyone runs upstream to the next holes so this is repeated until the fishermen are exhausted or another village is reached. In the latter case the people of the lower village must stop and the people of the upper village take up the pursuit. The lampreys swim slowly up the middle of the river, keep as close to the surface of the water as possible in a compact mass, and require an hour or more to pass a given point. ${ }^{34}$

\section{Physical Development and Character}

As a rule, the Yukon Indians are small-sized people with small feet and hands. The Anvik people and other Indians between Anvik and Paimiut have rather thick features with flat noses and seem almost as though their facial characteristics had been graded towards those of their Innuit neighbors.

The people of the Innoko River, Nulato, and up along the Yukon all show a large proportion of hooked noses and the typical Indian features. The men are slenderly built, but are very active. There are a few very large men among them and I saw several men from among the Anvik, Innoko, and Nulato people who reached $6 \mathrm{ft}$. or over, but they merely served to mark the almost stunted appearance of their fellow tribesmen.

The Indians of the Innoko River are very excitable and fond of showing this in certain ways. When the Territory was first taken by 
the Americans the people of that district had a reputation of being hostile to the visits of strangers. The first fur traders who went to their villages were met at the largest place by a great crowd of Indians all armed with bows and arrows and whooping, yelling, and making all manner of hostile demonstrations. The traders stood their ground and after a time they were escorted to the village and were soon established there on a friendly footing. Since then regular trading trips are made among them. ${ }^{35}$

On my visit to them in December, 1880 we found nearly all of the men and boys of this tribe, numbering about 60 , gathered above the village to take part in one of their festivals. As we drew near, the entire village rushed out on the river bank and greeted us with the most frightful yells and shrieks and evidences of the wildest excitement. This was merely their way of extending a friendly welcome. ${ }^{36}$

These people are brave and quick to resent any injury, real or fancied. Formerly, when they were more numerous, they were much more independent and pugnacious than at present. There present condition as a mere remnant of their former numbers has taken away their confidence and causes them to be much more timid than the Yukon Indians. ${ }^{37}$ As is usual with savages, the Yukon Indians are thoughtless and improvident and have a childlike way of permitting tomorrow [to] care for itself.

An incident that came under my notice served as a good illustration of this. While descending Anvik River the last of November, 1880 , we camped at a deserted village one night. With us was an Anvik Indian who had come from the seacoast with a large bag of seal oil. When we went into one of the deserted huts for supper this Indian left his bag of oil lying upon the ground in the midst of the dogs and went with us. A few minutes later the dogs had torn open the bag and destroyed its contents. On inquiry we learned that this young fellow had made a lot of wooden tubs during the preceding summer and had taken them by boat to St. Michael, a round trip of over 500 miles. There he had left the tubs in payment for the bag of oil to be delivered in the early winter. He had just been back to the coast with his sledge and brought the oil back within a day's journey of home and had thus lost it by sheer thoughtlessness. This oil was intended for lighting his hut during the winter. ${ }^{38}$

He took its loss very indifferently and when the fur trader and I told him we would make him a small present to help make up for his loss he became as cheerful as before and was soon laughing and jok- 
ing with our men without a care. They make very little or no attempt to accumulate food or property beyond the bare necessities of the immediate future, so that a failure in the usual abundance of fish or game in any season is an almost certain forecast of a famine.

Almost every winter a season of distress arises among the Indians at some point of the Yukon Valley and frequently many deaths occur from starvation. ${ }^{39}$ The winter of 1879-1880 the fur trader at Nuklukayet saved many of the people about him from starvation while many of the people in that district died. ${ }^{40}$

The custom of accumulating property through one or more years for the purpose of making a festival in honor of dead relatives, at which the property is distributed among the people, is looked upon as praiseworthy. ${ }^{41}$ For anyone to try to accumulate property with a view to his personal advantage is considered a species of disloyalty to the public interest and gives rise to jealousy and ill will.

The fur traders told me of a practical illustration of this in the case of an Indian living on the Yukon above the mouth of the Tanana River. This young man was a very good hunter and by his industry and success he managed to gather quite a store of furs and other property. Then he built himself a log house apart from the village and went to live in it with his two younger brothers. At the same time he showed the greatest eagerness to learn the ways of the white man and adopted some of their ways of living.

The men of his tribe talked this over and decided that his course was wrong and that by thus withdrawing from the general community he had violated his duty to the tribe. The result was that a party of his fellow townsmen went to this house and killed him and his brothers, his property was distributed, and thus the young men were taught to continue in the ways of their fathers. ${ }^{42}$

These people are very fond of singing and dancing and when they accompany the fur traders to St. Michael in summer the men spend a large part of the arctic summer nights in wrestling, singing, and dancing. ${ }^{43}$

They have a great dread of anything unusual, fearing witchcraft. When at Anvik I had a large group of women and children arranged in front of the camera and when ready to expose the plate I had the interpreter tell them to stand still. The moment he said this every one of them made a rush for home and they darted into the houses like rabbits. It was only after the greatest effort that I finally got them out again and obtained a photograph. 
The children are very dutiful and affectionate, while the parents show the greatest fondness for them in various undemonstrative ways. The women on the Innoko River were excessively filthy in dress and person, but most of the Indians of the Yukon Valley are as cleanly as is customary among Indians.

\section{Customs and Beliefs}

In the account of the burial customs and religious festivals can be found many of the beliefs and observances of some of the Yukon Indians.

The land of the dead is situated underground and the shade of the dead sinks down to it and travels away along a beaten path to the great village where the shades live in a world formed as a shadowy likeness to the present life. ${ }^{44}$

The shades experience the emotions and feelings familiar to them on earth. The custom of blood revenge for the murder of any person falls to his family and the soul is uneasy and dissatisfied until his death has been atoned for by the death of his slayer. In the case of the latter's death, or escape by going beyond reach of the avengers, then his nearest of kin or one of his family must pay the penalty.

The duty of carrying out the blood vengeance falls to the dead man's son or failing in this to his brother or nearest of kin. This is looked upon as a duty which must be performed. An infant child sometimes inherits a feud in this way and consummates the revenge 15 or more years after the first murder was done. However, by the payment of a satisfactory price, the murderer may atone for the deed and stop the feud without bloodshed. In order to do this, the matter must be submitted to a council of the elders and the price, agreed upon by them and accepted by the dead one's relatives, is then paid to the relatives through the council and the affair is considered to be amicably settled. I knew of a case at Nulato when a young man killed an Indian and the latter's brother and friends pretended to compromise the matter and accepted payment from the father of the murderer and, on the first opportunity, the old man was shot down in cold blood for his son's deed. The Indians justified themselves with the plea that the compromise had no binding force on them because they had made it with the man without the intervention of the usual council of elders. ${ }^{45}$

The strip of country back from the coast from Norton's to Kotzebue's sounds is a debatable land between the Malemiut In- 
nuits and the Indians of the interior and an opportunity is rarely lost on either side to kill one of the others. The country in question is a hunting ground for reindeer [caribou] by both parties and each side watches its opportunity to ambush one of its hereditary foes.

Formerly, regular war parties went from one side to the other but of late years this has become almost unknown. Great suspicion and dislike still exist between the Innuits and Indians, but the constant communication between these people that the presence of the fur traders has brought about is doing away with much of the ancient prejudice. $^{46}$

Among the Anvik Indians, when a girl has her first menstruation she is considered unclean and a corner of the hut where she lives is shut off from the rest of the house by hanging up grass mats and she is obliged to remain in this confinement for a year. During this period she must keep her fur hood drawn over her head and a black band is drawn with soot or charcoal across her eyes from temple to temple just as is done with a dead person. She must eat only stale food during all of this time and must not go about nor join the family in any of their work or pastimes.

If the family moves during this time she is carried out and put into the sledge or boat and covered up and thus taken to the new place and left in a corner as before. She is permitted to go out of the house only in the middle of the night.

When first shut up she is obliged to wear a pair of small mittens just large enough to admit her fingers. These mittens are joined by a short band of ornamented strips of fur extending across the back of her neck and keeping the mittens on a level with her breast. She must keep these mittens with her during the entire year but wears them only at first.

Throughout this year her urine is thrown in some secluded place where no men go, for it is considered to be unclean and would destroy a hunter or fisherman's success if he should be contaminated by it in any way.

At all subsequent recurrence of the menses women are not permitted to eat fresh food of any kind and are unclean for a few days.

At the expiration of the year the girl takes a bath, her old clothes are thrown away, and she is given an entire new suit. A fillet of reindeer [caribou] skin or moose skin ornamented with fringe or tassels is worn about her head as a mark of maturity. This is often 
made of birch bark covered with skin and is worn for a year after the expiration of her period of confinement. ${ }^{47}$

When a women is confined with child among these people she is not separated from the family and the old women serve as midwives. ${ }^{48}$

When an Anvik Indian desires a girl for his wife he chooses some old person as a messenger and sends to ask the girl if she will be his wife. If she consents, the messenger goes to the girl's parents for their consent without which she may not marry. If the parents consent, the messenger takes their reply to the lover. The latter then has a fine suit of woman's clothes made and with a deerskin for a bed, [they] are taken to the girl by messenger. The girl is dressed in the new clothes and the lover goes to the wood and gets a lcad of firewood which he cuts up and places before the door of his lover's house. He also makes her some new wooden dishes. After all of these things have been accepted, the lover takes the girl as his wife and the couple usually live with his parents, but should he have brothers and his wife's people be without sons, he sometimes lives with them. Very soon after marriage the husband is expected to make a fish trap and puts it out so as to provide for his family.

A girl often has several offers before she is married. Even when willing to marry her suitor, the parents will refuse consent if the youth is a very poor hunter or not able to provide for his wife as they think right. The refusal of the consent of the parents, real or adopted, always ends the matter. ${ }^{49}$

After a man is married, his wife may be taken from him by a rival. If his wife has her regard estranged by another man and the lover wishes to take her, the husband may keep her only by conquering his rival in a trial of strength. Custom demands that before a lover can take a wife from her husband he must show himself the best man. A meeting is appointed and the husband and lover have a wrestling match in the presence of the entire village. The victor in this takes the woman. The lover always assures himself of the woman's favor before he enters a contest and if victorious he continues to live on in the same village with the woman's former husband in the most friendly way. If he loses, he is forced to give up his hopes. Very rarely the rivalry for a woman's favor leads to bloodshed, but this is strongly condemned by the community..$^{50}$

Among all of the Yukon Indians the old men are respected and 
consulted and usually obeyed by the younger ones. The shamans and the most powerful men or the best hunters are the men of most weight in deciding any important question. The shamans are jealous of their power and use all the means in their power to keep up their influence. Of late years the younger men are losing some of the respect and obedience they formerly gave to the elders. ${ }^{51}$

The Anvik people, or those of them who still observe the ancient rites, will not sell fish to white men for three or four days after they are caught in winter, fearing that the bones may be given to the dogs before the expiration of that time. In such case, the shades of the fish would be offended and would keep any other fish from entering the trap of the person who had offended them.

In summer they will sell fish the day they are caught, if the buyer will agree not to eat the fish until the next day.

The Tanana Indians are very careful to preserve all the bones of a lynx and place them where they shall not be disturbed by a dog. If the flesh of a lynx is sold to a fur trader, the Indian insists that all of the bones shall be preserved and returned to him that he may keep them from being touched by a dog. They say that if a dog eats any of the bones of a lynx then the person who caught it will not get any more lynxes in his snares. ${ }^{52}$

Any unusual capture in a trap is always feared as of ill omen. In one case, a Tanana Indian caught a wolverine in a lynx snare and found the wolverine hanging quite dead. To catch so notoriously cunning an animal as a wolverine in a simple trap like this was almost beyond precedent and the hunter returned home at once not daring to touch his capture. He consulted the old men of the village and the shamans and studied over this strange thing for some days. Finally, his cupidity overcame his superstitious fears so that he returned and drew the animal out of the snare, but, to deceive the shade of the animal and shift any evil consequences from his own shoulders, he uttered over and over again as he was doing so "g-d---- americanski, g-- d--- americanski" a combination of English and Russian which he had picked up from the traders. He returned to his village quite elated over his happy solution of the trouble and told how he had overcome any evil that might arise by throwing it upon the traders. ${ }^{53}$

The Yukon Indians from Nulato to Fort Yukon have superstitious dread of interfering with the nest of the Canada jay saying that it 
will cause a very cold, bad spring. The fur traders at the mouth of the Tanana managed, for a large reward, to get me a nest of this bird from one of the Indians and, as it chanced, that spring became a very cold and stormy one. The old Indians at once united in denouncing the cause of this in the person of the young man who had flown in the face of the ancient wisdom and taken a jay's nest.

The Shageluk Indians believe in the existence of a huge pike in Shageluk Lake which they say is as large as a birch canoe. One of the Anvik men told me that he had been pursued and driven ashore on Shageluk Lake by this pike and the Shageluk men told me a circumstantial tale of one of their fellow villagers being attacked by it on the lake. First, the fish bit a piece out of the man's paddle and then tore a large hole in the canoe so that it sank and the man was drowned.

The canoe and paddle drifted ashore and showed the marks of the fish's teeth. The pickerel of the Yukon are of such a small size that this fish must be almost wholly mythical though it is firmly believed in by the people living about the lake. ${ }^{54}$

Until the country came into the hands of the Americans, the Kolchan Indians wore the usual painted Chippewayan dress of dressed moose or deerskin. The active trade carried on since that time has broken down the ancient customs to such an extent that at present (1880) these people dress wholly in clothing bought of the Innuits or of the fur traders and the old pattern is seen no more. The old Chippewayan style of dress is being replaced all along the Yukon Valley by clothing bought of the traders or made on patterns introduced in this way and the distinctive dress of a few years back is being rapidly lost..$^{55}$

\section{Villages and Houses}

The Yukon Indians have steadily decreased in number for years and without any apparent chance for regaining their former numbers. One tribe above Fort Yukon is very scantily supplied with women owing to the fearful hardship the men force their wives to endure in bringing meat to camp after hunts and similar drudgery. The result has been to cause the women to die so rapidly that the men have been forced to seek wives among the people along down the Yukon. The women obtained in this way went as did their predecessors and the men from that district have great trouble getting wives. In the vicinity of Nuklukayet several famine years have cut down the number of people. 
The Kol-chans living on the Innoko River and adjacent territory were once a numerous tribe having several hundred men. Smallpox and other diseases have reduced their numbers until the total number of men and boys of this tribe today (1880) cannot exceed 60 to 65 . During my visit to the Innoko, the fur trader of that district

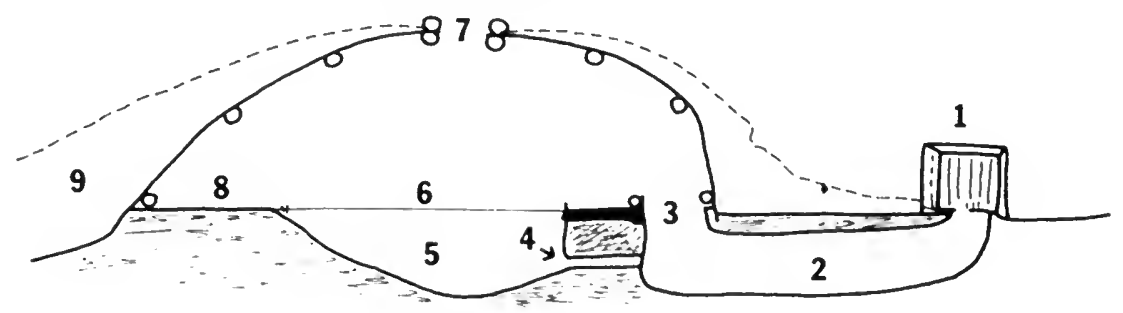

FIG. 4. A kashim on the Innoko River (approximately $16 \mathrm{ft}$. square). Drawn and described by E. W. Nelson. 1, Entrance shed; 2, Underground entrance passage; 3 , Inner entrance; 4, Draft tunnel to fireplace; 5, Fireplace or pit; 6, Plank floor; 7, Smoke hole in roof; 8 , Dirt floor; 9 , Earth cover to house.

and I estimated the total number of people left in this tribe not to exceed about 125 . To make matters still more hopeless, the women are nearly all barren and game is scarce. ${ }^{56}$

These people (Kol-chans) have built themselves half-underground houses, like those of the Innuits in general plan, for some years and three or four years ago they built kashims in several of their villages. The latter now serve as sleeping places for the men and in them are held the festivals.

The sweat house where I witnessed a festival on the Innoko River was built half underground and as its plan differs somewhat from the usual style, the following section and description will explain its main features. It had the usual smoke hole in the roof. The middle of the room in a square about $8 \mathrm{ft}$. across was floored with rough hewn planks. These covered the shallow pit used for a fireplace, the planks being removed when a fire is made. All around the room off these planks was a beaten dirt floor. The walls of the house were of small logs and the sides and roof were covered with a thick layer of earth. There were no sleeping benches around the sides of the interior of this or any of the other Innoko sweat houses I saw. A small shed covered the entrance outside and an underground passage led into the house and up through the floor at the front end of the room. On the inside of the room this opening had a raised ledge about it to cut off any draught. From the entrance passageway a small tunnel leads 
under the floor to the fireplace thus affording the necessary draught there. The following is a cross-section of this sweat house made on the spot (fig. 4). This house was about $16 \mathrm{ft}$. square and $8 \mathrm{ft}$. high. ${ }^{57}$

The lowest village on the Innoko River, about 35 miles above its mouth, has raised storehouses and sledge platforms, or frames, and half underground houses very much like a village of the Yukon Innuits. At this place the summer village of light brush and barkcovered huts stood close beside the winter village made of the underground houses mentioned..$^{58}$

Anvik village is built on a low spit at the mouth of Anvik River and is being gradually washed away by the river and rebuilt a little farther back each year. The houses are modeled after those of the adjacent Innuits. There is a large sweat house here of the ordinary pattern. The walls of the houses are made of saplings and the roofs are usually covered with wicker panels from old fish traps, laid on poles and covered with slabs of spruce or birch bark. A sleeping platform built of poles usually occupies the back end of the hut. These summer villages contain no kashims.

\section{Implements and Trade}

At the Anvik summer village just below the mouth of Anvik River I saw a number of very large clay pots. They were about $2 \mathrm{ft}$. high and $18 \mathrm{in}$. across. For such large vessels their walls were very thin. These pots were uniformly shaped as follows: they are placed on the ground and a fire of sticks built about them to heat the water and thus cook their contents. The women make them by kneading a stiff clay with hair or fine feathers and then bake them with a hot fire inside and out for half a day..$^{59}$

The people of Anvik and Shageluk Island are noted all down the Yukon for their fine wooden tubs and dishes, or kantags, and every summer the people from this district go down the Yukon and along the adjacent coast carrying these things for trade with the Innuits. In this way they buy seal oil and sealskins for lights and for making their boots and covering their umiaks.

Although the canoes used by the Indians of the Yukon are all made of birch bark, yet the Indians of Anvik and the Shageluk have adopted the Innuit umiak and make long summer trading voyages in them. The Anvik old men who are not able to travel about and attend to traps occupy their time in making kantags or wicker fish traps for trade. 
Dried salmon form another article of trade which these Indians take to the seacoast. Their voyages are usually made in the fall after the fishing season is over. ${ }^{60}$

A fine jadeite celt was found, several years ago on the side of a mountain, a day's journey above Nulato and north of the Yukon. An Indian was cutting down a spruce tree and found this celt completely imbedded in its trunk. I was fortunate enough to secure this specimen and the Nulato Indians told me that not far from where it was found is the locality where they went formerly and found rough pieces of jadeite like this which they traded to distant tribes ${ }^{61}$

The unit of value used in trading among Yukon Indians is a prime beaver skin or a marten skin. All other furs and articles are bought as fractions of a "skin" or multiples of a skin in value. ${ }^{62}$

\section{Raven Tale of the Stolen Wife: From Anvik Indians}

(Among the Indians of the lower Yukon, from Nulato to the vicinity of Paimiut, and particularly among the Anvik Indians, the intercourse has been so free and long-continued with the adjoining Innuits that a great number of legends, festival observances, and other customs have been taken by them from the Innuits. That the adoption has been by the Indians from the Innuits is sufficiently proved when the fact is known that the custom or belief is general among the Innuits and only found among Indians along the border of Innuit territory.-E.W.N.)

In a large village on the lower Yukon very long ago there lived four brothers and three sisters. All but the youngest brother and sister were married. All of the brothers and sisters were very handsome people, especially the two younger ones.

One night the youngest brother could not get to sleep until nearly morning for something seemed to trouble him. When he awoke it was midday and everyone had gone out of the sweat house except himself and a strange looking object, lying close to the entrance way, upon a dogskin and with a dogskin blanket drawn over it. $\mathrm{He}$ arose and went out brushing close by the strange object as he did so for he had never before seen dogskins used in this way.

When he got outside he saw drawn up on the river bank a canoe covered with fishskin. The strange apearance of this canoe caused him to make an exclamation of surprise and he saw at once that it must belong to the curious being he had seen in the sweat house. $\mathrm{He}$ 
thought, "Perhaps this man has come for my sister." He asked and found that his sisters had crossed the river for berries and he went out to the mountains to hunt for reindeer [caribou].

Soon after this, the Raven, who had been in the sweat house disguised by the dogskins, came out and crossed the river in his canoe. Then he took the canoes of the sisters and towed them across the river to the village and left them. After doing this Raven went back and cut a spruce root and began making wooden dishes and ladles (the custom of a lower Yukon Indian lover) and worked at this the rest of the day. Toward evening the two oldest sisters came down to the river bank and, their canoes being gone, Raven took them across in his and the two women went home without thinking anything wrong. The Raven went back and took the youngest sister in his canoe, but when he had pushed out into the river he turned up the stream and paddled away from the village with great swiftness.

At this the girl shrieked for her people until she was unable to do so any longer and then began to cry very bitterly; all the time Raven was paddling swiftly and silently away. At last the girl began to upbraid him and asked him why he was taking her away. He answered that he wished her for his wife and was taking her to his home up the river. The girl continued to cry and told him that she did not wish a husband, but he paid no attention.

When she became hungry Raven gave her one of his new wooden dishes in the bottom of which was a nice piece of reindeer [caribou] meat and some back fat. This he gave her telling her at the same time that he would always feed her well like this when she was his wife. Again she told him that she did not wish to be a wife and begged him to let her go home. Day and night Raven paddled steadily onward, never stopping, and the canoe seemed to dart onward like an arrow.

In this way many days passed by and the Yukon began to get narrow. Autumn came and the canoe (whose fishskin cover had long since changed into birch bark) glided on day and night, and it became so cold that ice formed on the paddle-blade at night.

Then the Yukon became quite narrow and Raven pointed to a high mountain ahead and said, "My home is near that mountain and we will get there soon." They went on until the river narrowed to a deep creek and had high rocky walls on both sides as it cut through the mountains. Not far beyond this was Raven's summer village, close to the high mountain. 
As they came in sight of the houses they saw a mink come swimming toward the canoe and Raven exclaimed angrily, "There is that wretched mink again" and he fitted an arrow to his bow and shot it, but the mink dived to escape it and came up close to the canoe and cried out, "Ah! You rascally Raven, you wish to kill me do you? Good-for-nothing. You just missed doing it. Another wife is it? You are a bad Raven; why are you always carrying off young women? Are you not satisfied with those you have now but you must steal others?" The mink dived again and swam down the river and the canoe kept on.

When they were close to the Raven's house he gave the girl some fine new clothes and he put on a rich coat of sable [marten] skins himself and then told her to follow him into the village where his four brothers were waiting for him. Now, after the mink had passed Raven and gone a short distance he stopped and thought "Ah! That bad Raven. He wished to kill me, and he barely missed me too, with all his other badness. But I will be revenged, I will go and find this girl's people and betray his hiding place." With this the mink started off and traveled down the river. He stopped at night in every village he came to and stealing quietly into the entrance passages of the houses would lie there and listen to what was said by the people. He was sure to hear the girl spoken of when he came to her village.

After he had traveled a very long time and been in many villages without success, he came, at last, to a very large place. When he went into the passageway of a house there he heard the people talking about the lost girl and crying for her. Just then one of the people caught a glimpse of mink and called for a light, and they searched but saw nothing. When they went back into the house, mink changed himself into a dwarf man dressed all in mink fur, even to the tips of his fingers, and walked into the house.

The moment he went in the young brother of the lost girl cried out, "Here is a guest. It is the first we have had and perhaps he can tell us of my sister. But first give him food and water and treat him well, and then we will question him." The brother then hurried out to call the other brothers from the sweat house.

As soon as mink entered the house the lost girl's mother took him up in her arms eager to question him, but put him down again to give him food and water. When mink had taken food and water the mother caught him up again and questioned him eagerly while the others gathered about. Mink told them of Raven's treachery and of 
his journey to tell them of it. Then all of the active young men in the village agreed to go and punish Raven.

They made new arrows and when all were ready they started out guided by mink. The war party traveled on month after month during all the winter and in the long days of spring they came to the head of the Yukon and saw, on the other side of the river, the mountain that sheltered Raven's home.

Mink then told them to stay where they were and await a signal from him and he would go and see what lay before them. He quickly changed his form into a mink again and burrowed into the snow and tunneled across the river coming up the other bank close to Raven's door. In front of the door were two of Raven's brothers guarding the entrance. These brothers were each made of the right half of a man, the left side being entirely lacking.

As mink came near he heard them making a great outcry about mink and the men who were with him, but they did not stir from their place on each side of the door. Mink watched for a chance and darted by the guards and into the house and hid under a pile of wooden dishes without being seen. Raven sat on the sleeping bench in the house beside his stolen wife.

Mink watched and when Raven looked the other way he rattled the dishes. At this the girl went over to pick up some that had fallen down. As she raised one of them mink showed himself to her and said in a low voice, "Do not sleep tonight, Your people will come for you tonight."

At this moment the two guards rushed in and caught Raven by the hair and shook him crying, "Wake up! Who is your wife talking to? We saw her mouth speak and many people are coming to fight you," and the guards went back to their place outside the door. When the guards went out the girl said, "What are your brothers crying about now? I suppose a mouse is stirring outside." When Raven heard this he forgot about the warning and believed his wife.

Every little while the brothers ran into the house and caught Raven by the hair and shook him fiercely and cried out their alarm, but every time Raven's wife would persuade him to pay no heed to it. While standing by the door the brothers kept up a constant cry of "hoo-hoo, hoo-hoo" which became very low every now and then when they became sleepy and dozed and louder when they awoke. 
Waiting until the guards were dozing, mink escaped by them and returned to his friends. When the night had nearly passed the war party drew around Raven's house, but found it closed tightly all over, as if made of a solid stone, and the guards were asleep inside. They searched about until they found a crevice in the roof through which they could see Raven seated below.

They began shooting arrows at him and Raven ran wildly about in the house until one of the arrows killed him. Then they pulled off the roof and as they did so one of the guards flew away into the sky and the other one vanished into the ground.

The brothers were very glad to get their sister again and from an adjoining house they released many captive women who had been stolen from their friends by Raven. One of these, a very pretty girl, the youngest brother took home with him as his wife. Mink went back with the brothers and married the sister he had helped rescue. ${ }^{63}$

\section{Raven's Search for His Friend's Wife: From the Anvik Indians}

Four brothers once lived in a large village on the Yukon River. Three of the brothers were married, but the youngest one was not. The three oldest brothers were ordinary hunters, but the youngest one delighted in hunting and was always successful.

At last his mother spoke to the young man saying, "My son, why do you not take a wife? You are the best hunter in the village and you should choose someone to share with you." To which he replied that he did not wish for a wife and would rather live as he was. After this he went on as before, hunting every day and sleeping in the sweat house at night.

One night he was lying in his place, opposite the entrance to the sweat house, when he saw Raven, who was always lying on a bed near the entrance way, get up and go directly to him. For in those days Raven lived in this village with men. When Raven came to the young man, he said, "Why do you not choose you a wife? You are the best hunter here and you should have some one to do your sewing and your other housework." To this the hunter replied as before that he did not wish to marry and, if he did, there was no one in the village whom he cared for. "I do not know the young women," said Raven, "as I do not go about in the village, but I have heard that there is a fine young woman living far down the river."

Then Raven went back to his bed and laid down. When everyone was asleep he stretched out his feet from under his blankets, show- 
ing the three toes on each foot, and got up. When he had gone outside carefully, he looked about him and saw four storehouses close at hand. One of these belonged to the young hunter and to this Raven went. In it he found a fine coat of sable [marten] skins also fine breeches and boots. After he had put on these he looked about and found a piece of deer fat which he put under his belt and then started down the river.

He traveled on for many days and after passing several villages he finally came to a very large place. He stopped at the edge of the village and looked about him.

Very soon two women came toward a house close by and Raven ran quickly ahead and laid down beside the door. The women came along and were talking about a very nice young woman who had no husband and lived in the next village below this one, on the river. The women could not see Raven very plainly, and mistook him for a clod of earth. When Raven heard this and heard one of the women say that she did not think the young woman would ever have a husband, he thought, "Ah! I will make this young woman a visit tomorrow."

Raven traveled on and the next night came to the village where the girl lived and found it to be a very large one. As he came near he heard a dog howl once and then everything was quiet. He went on very cautiously and, near the edge of the village, saw a house that had its entrance guarded by two great dogs as large as bears, one being tied to the door post on each side. Raven at once thought that the girl must live here, and he stood there for a long time trying to think how he could pass the dogs.

After a time he searched in his hair and drew out a louse, and from under his belt he took a crumb of the reindeer fat which he had brought from the storehouse, for he ate very little and only once in every two or three days on his way to this place. He rubbed the louse and the fat together in the palm of his hand and then threw them to the dogs.

The latter ate them up at once and then began to fawn upon Raven and made no effort to stop him from going into the house. When he came to the end of the dark entrance passage he felt about for a door and could find nothing but a narrow crevice. Into this crack Raven put his bill and, after thinking a while, he raised his hand and struck himself a sharp blow on the back of the head. When 
he did this he instantly turned into a slender bone needle and the force of the blow drove him through the crack and he fell inside on the floor. As soon as he touched the floor he turned back again into his proper shape.

Then he looked about and saw that the only person in the room was a woman lying asleep on one side. He went up to her and saw that she was very nice looking. Raven felt ashamed and hesitated for some time and then he went up to the woman and shook her gently. This he repeated several times without awaking her and then he said to himself, "I do not think this one is so very fine," and he began to feel all about the walls until, right opposite the entrance, he found a crack at which he worked until a door came open and showed an inner room. On one side of this room lay the most beautiful young woman Raven had ever seen and he felt still more ashamed than when in the outer room.

After hesitating for a time he went up to her and shook her lightly. She was wrapped from head to foot in her blanket and did not stir. Then Raven took her up under his right arm and, carrying her out of the house, started back up the river with her still under his arm.

After traveling all night he became very tired and stopped to rest. Then the girl awoke and he told her that he was taking her to be the wife of a fine young man who was the best hunter in his village and who had no wife. To this she made no answer. Raven gave her some reindeer [caribou] fat to eat and, after resting, they traveled on again.

So they went on and on until, one evening, they came to Raven's village. Raven thought for a minute and then drew a small rawhide cord from his pocket and tied one end about the girl's waist. Then he took the other end and carried it into the house.

He found the young hunter sitting opposite the entrance with his father and brothers on the sides. Raven placed the end of the cord in the hunter's hand and told him to draw it in. He did so and very soon in came the beautiful girl Raven had brought him. Raven took back his cord and told the hunter that he had brought him this fine young girl for his wife and he must care for her kindly. The hunter was much pleased and promised to do so.

Raven took off the fine clothing he had taken from the hunter's storehouse and, leaving it on the floor, he went back to his place in the sweat house near the door. 
The hunter loved his wife very much and hunted for her more successfully than ever. Thus they lived happily until she fell ill. She had a headache and pains all over her body. The hunter sat with her day and night, quite giving up hunting and trying to help his wife.

After watching her for several days, he became very tired and while sitting by her side one evening his eyes closed for a minute and his head nodded, heavy with sleep. He was awake again in a moment and was very much alarmed to see that his wife had disappeared. He gave the alarm and, with his brothers, searched about the village all night without finding her. Morning came and the entire village joined in the search and they looked far and near, but, although she was gone, not even a track in the snow could be found to tell where.

Several days passed during which the hunter never rested in his search. During this time he had been joined by Raven and, after thinking a while, the latter started off by himself and visited several neighboring villages without finding the woman.

Then he started up the river and traveled a very long distance until he came, finally, to a very large village close to which arose a high mountain. Raven flew up and perched upon the highest rocks on this mountain top. Here he sat and watched the people passing from house to house below him.

As evening drew near a young woman came out of the sweat house and went for water. She was close to the door on her way back when Raven, who had been trying to think of some way to get a look at her face, felt in his belt and found a small stone which he cast down. It fell at the woman's feet and when she looked up Raven saw that it was his friend's wife.

At the same time she saw Raven perched on top of the cliff, but said nothing. She took the water into the sweat house and, coming out again, went behind the house and looked up. Raven felt in his belt and drew out a piece of cord as long as his finger. This he took in his right hand and made a throwing motion with it.

When he did this the loose end of the cord began to stretch out farther and farther until it reached right down to the woman's feet. She took up the end and made it fast to her wrists. Raven then drew in on the other end and pulled her safely up to him on the mountain top. He had just untied the cord from her wrists when he saw a great 
broad-shouldered fellow come out of the sweat house and look around.

Raven knew him at once as the one who had stolen the woman, and, making a noose at one end of the cord, he threw it down again and it encircled the man's neck. Raven began pulling away at once and dragging the man up the hillside. The man struggled and cried out at first, but was dead when he reached the top. Then Raven took a stone and broke every bone in his body and threw him back into the village.

They then traveled back down the river and reached their own village after a long time. The hunter was filled with joy to have his wife again and Raven told him how he had taken her from the shaman who had stolen her. Raven went back to his place by the door of the sweat house. ${ }^{.6}$

\section{Tale of the Returned One: From an Old Man at Anvik}

A man died and his shade left his body and started for the land of the dead. He started off underground and followed a broad road with smaller ones branching off from it here and there. These he saw were roads leading to the places inhabited by the shades of the different kinds of animals. He kept on, overtaking the shades of many men and, after passing one village occupied by the shades of men, he came to the village occupied by the shades of dogs. Here two shades guided him around this village telling him that it was not safe to go through it.

Before long he came to a stream as black as night, and made so by the sweat of dead men. He crossed this in a canoe he found on the shore and went on by another village. Then he came to another stream very clear and bright and formed of the tears of those who mourn for the dead.

He passed this in a canoe and, on the fifth night, came to where the road ended abruptly against the foot of a high cliff. On the top of this cliff he saw great numbers of shades which he knew were those of good people living there in a land of plenty with a pleasant light. In all the lower land where he was it was gloomy and unpleasant.

While he stood looking up at the cliff, an old man called out and told him to go away on another road there was near him and to beware looking at any of the shades he should meet on the way, even if they called to him. 
He started off on this road as directed and in four days he reached his grave and going back into his body he arose and went home again, where he told what he had seen.

He saw many villages of shades scattered along the road and learned that the worse a man was when alive the shorter distance he could go into the land of the shades, and the more unpleasant his surroundings were. The shades of liars, thieves, and murderers have but little to eat. The shades of good people and those who die an ordinary death travel on until they reach the high land at the end of the road and are happy in a land of plenty.$^{65}$

\section{Tale of the Two Shamans: From Nulato Indians}

Near the Yukon River once stood a village containing many people. One day a strange sickness began to attack the people there and man and women would suddenly fall on their backs and die, while the fear and sorrow of the survivors was very great.

At that time the Raven shaman lived in their village and the people ran to him with many rich presents of furs and other things and begged him to help them before they all died. He accepted their offerings and prepared himself for the trial.

When he was ready he went outside of the sweat house and walked slowly around it examining the snow. Just behind the sweat house he found an ermine track leading from under the house out into the woods. Ending his search here Raven cried, "Ah-h! Perhaps you are what I am after."

Then he followed the track far away from the village until it changed, at last, into the track of a man. He followed this for several days until it led him to a large village. Raven looked about and saw a house near the sweat house and he entered it and sat for a time in the manner of a guest until he heard the men of the village come out of the sweat house where they had been taking a sweat bath. He went to the doorway and peered through a crack at the men, but was disappointed and said to himself, "It was none of those men," but, just then, a large powerful man came out with his eyes shut tightly, being blinded by the smoke in the sweat house. Seeing him Raven thought, "That is the one," and, as he thought this, the Ermine shaman, whose back was toward Raven, cried out, "Who is looking at me? Some stranger is looking at me."

Before long the men went back into the sweat house and Raven 
went with them. Then the women brought in food and the Ermine shaman asked Raven to eat with him. Raven went and sat down by him and tried to think of some way to kill him.

The Ermine shaman suddenly exclaimed, "You need not try to hurt me. I know what you are thinking about, and you had better eat with me." At first Raven was afraid to eat until the Ermine shaman began and then he did the same, still trying to think of something to do to the food to kill the Ermine shaman. "Do not try to hurt me, for I am watching you," said the latter. When there was only a small morsel of food in the dish, Raven managed to insert into it a small black object and it was swallowed by the Ermine shaman.

Soon afterward they laid down and in a little while Ermine shaman became very ill and cried to the Raven, "What did you do to the food? If you do not cure me of this sickeness that you have given me you will be sorry." To this the Raven [replied] "Why did you go and make so many of my friends die? Now I have you and you will not get well for I will not help you." The Ermine shaman groaned and said, "Cure me, for if you do not your life will end with mine." Raven would not help him and started back home.

As he went on he began to feel himself becoming more and more ill from the spells of the Ermine shaman and he hastened on night and day to reach home before he died. When he reached his village he was so ill that his people had to carry him into the sweat house. There he lived just long enough to tell the people the cause of his death and what he had done for them when he died.

His grave box was made and in it with him was placed his bag with the flint and steel for making fire and about the box were strewn his bear spear, snowshoes, bow and arrows, and axe. When the body was placed in the box the shade felt itself sinking slowly down, down, until he found himself standing on the bank of a river just like the Yukon near his village.

Scattered about him, on the snow that covered the land and the frozen river, lay the tools and articles that had been placed about his grave box. After he had gathered them up he looked about him and saw the tracks of the Ermine shaman leading away up the frozen river on the ice and he followed the track.

By and by he saw the Ermine shaman walking slowly along and when he saw Raven he stopped and waited for him to come up. As he 
drew near Raven thought, "Ah! If I could only kill him again that would end him." Ermine shaman felt this thought at once and said, "Have you not done enough, that you still wish to do me harm? We are both dead now and that should be enough." "All right," said Raven, "let us travel on together, as we are going the same way." So they went on and at nightfall they came to the ramparts of the Yukon. (This is 300 miles above Nulato, their supposed starting place.)

With his axe Raven cut a pile of logs and they built a fire and, seated by it, they ate of the food their friends had placed on their graves when they were buried. Each gave the other some of his food and then they went to sleep.

The next morning they arose and Raven placed together the charred ends of the logs left from their fire saying, "Our friends in coming after us to the land of the dead will see our fireplace here and will always, hereafter, make this their first stopping place."

Then he turned to the Ermine shaman and cried, "Well! Which way are you going to take now?" The latter answered by pointing in the direction of the North Star and said, "I am going there." "Where are you going?" he asked; and Raven pointed over the eastern horizon. "Very well, I am going," said the Ermine shaman and he began floating slowly up toward the sky.

He had gone but a little way from the ground when Raven raised his bear spear and cast it at him with so true an aim that it pierced the shaman in the small of the back where it stuck fast. When the spear struck him the Ermine shaman cried out in pain, bent his body forward, and threw back both hands, and, in this position he floated up and became the constellation of the Great Bear. And ever since he has turned around and around in the sky with the spear fast in his back, as anyone can see.

The Raven then walked far off into the dawn and has ever since been seen as the morning star in winter. ${ }^{66}$

\section{Raven Brings the Light: Nulato Indians}

Very long ago people had the shapes of different kinds of animals, some being bears, some wolves, and of other kinds, and the earth was hidden by darkness.

It was so dark that when anyone went out to search for food the people formed a long line, by holding to one another's coats, extending from the village so that no one should be lost. 
In one large village were gathered some of all the different kinds of people and when many ways to get light were tried in vain, the people, at last, went to the Raven for help. They made Raven many fine presents and asked him to help them.

Raven promised to try and he started to look for the light, part of the time walking and part of the time flying, for he could change into a man or a bird whenever he wished to do so.

After a time he came to a solitary house and he flew up on the top of a solitary tree growing near and waited. A man came out and Raven called out in a loud voice, "Yu-khoi? Yu-khoi?" or, "Where is the dawn? Where is the dawn?" The man looked up in surprise and then, without speaking, he ran back into the house to tell the people what he had heard.

Raven saw that he must go farther and flew away and away until he was tired and lit on a tree near another house. The first person who came out was asked the same question and ran into the house without answering, like the first.

For many days he traveled on until, at last, far away on the horizon, he saw a faint glimmering of light which became plainer each day. Every day he came to a house where he asked for the dawn without getting an answer. One day, when the light had become quite bright, he asked the question again and the man told him that just beyond lay a large village where an old chief lived with a young daughter and kept the sun shut up in a bag. Raven hurried on and when he saw the place close by he went back a little and, flying up into a small tree, began plucking the leaves and covering himself with them. Then he closed his eyes and thought, "I have on a sableskin coat," and when he opened his eyes he found that he did have on one. He took two rolls of birch bark and put them on his legs and wished them into a nice pair of reindeer [caribou] skin breeches. From birch bark he made a pair of moccasins and from other things he made a complete suit of clothing for a young man. From the gum and bark of the spruce he made a long-bladed knife and sheath. Then he went on to the chief's house and was welcomed as a guest.

He stopped there for a long time, but could not find where the old man kept the sun. He wishes for it and the chief's daughter is in love with him and he marries her. Five days after they are married she gives birth to a son. When he is two days old this boy walks about and soon begins to cry. The old chief is very fond of the child and 
gives it all kinds of toys to quiet it but cannot, for Raven is thinking all the time, "Cry, cry harder."

At last Raven said to the child, "You must be crying for the sun your grandfather has got shut up somewhere." At this the child made more noise than before until the old man went to a hidden recess and drew out a bag. From this he drew out the moon and hung it up in the house where the boy could see it and the child became quiet.

When the old man closed the bag, Raven saw that it contained two other bright objects and he began to plan to secure both them and the moon. The only difficulty being the old chief who never left the house.

Having his plan ready, Raven made a voice cry out from outside, "The dogs are eating your fish." Everybody except Raven and the old man ran out. Raven jumped up as soon as they were gone and cried "Don't you hear? The dogs will eat all of your fish; go ahead. I will follow." And he hurried the old man out through the door before he had time to think.

As soon as the old man was well into the passageway, Raven ran back and putting the moon into the bag, flew out through the window in the roof with it just as the old man got outside. Raven lit on the first tree and opened the bag. From it he took out the first piece he found, which was the sun, and cast it up into the sky and daylight spread all over the earth. He drew out a second piece and cast it up in another direction and the moon appeared. The last piece he broke into small bits and cast them up into the sky making the stars, the two largest pieces making the morning and evening stars.

Having finished, Raven traveled back home again and whenever, on his way, he came to one of the places he had passed when going for the light the people made a feast for him and gave him fine presents. When he reached home the people made him a great chief and always supplied all of his wants so that he never had to work any more. ${ }^{67}$

\section{Bird Myth}

There is a pretty little myth of the Nulato Indians that the Redpoll Linnet went off to the lodge where the first fire was hidden and stole some of it for men. It took a single coal of living fire in its beak and flew away to give it to the people who had no fire, but in doing 
this the fire burned a black mark across the bird's crown and gave such a glow of rosy light upon its breast that the bird has kept these marks ever since.

The lower Yukon Indians say that the Milky Way is the track by Raven's snowshoes. They name the constellation of the Great Bear, the Moose. 


\section{NOTES}

1. This is the partner's potlatch described in considerable detail by Osgood (1940, pp. 427-428; 1958, pp. 73-81) and to a lesser extent by Chapman (1907, vol. II, pp. 32-34). Nelson missed some of its significance, particularly those aspects related to honoring the dead, but he rightly stressed its importance as a means of exchanging goods. Although generally held between neighboring villages of equal size, the partner's potlatch also served to facilitate exchange between more distant communities. Among the Koyukon, and probably the Ingalik as well, this ceremony or its equivalent was also a means of formalizing relations with neighboring Eskimos and establishing useful trade contacts between two peoples who sometimes viewed each other with suspicion and distrust (VanStone, in press). Ceremonies to which guests from one village are invited by messengers from another are widespread among Bering Sea Eskimos (Nelson, 1899, pp. 358-363; Hawkes, 1913).

2. Because of uncertainties concerning the extent of Nelson's travels on the Innoko River, it is impossible to determine the village in which he witnessed the performance of the potlatch for the dead. He appears to have arrived on the fourth and last day of this, the most solemn of all Ingalik ceremonies (Osgood, 1940, pp. 422-423; 1958 , pp. 138-143). The fourth night of the potlatch for the dead is always devoted to the hot dance (Osgood, 1958, pp. 143-146), which Nelson describes here. Theoretically, at least, the hot dance was supposed to increase the supply of game animals, but it also had an important social function which compensated for the austerity of the potlatch for the dead (Osgood, 1958, p. 143).

3. Nelson's account here more closely resembles Osgood's (1958, pp. 138-143) than does his rendering of the previous ceremony. A great feast of the dead which was held on the lower Yukon at Razbinsky (near Pilot Station) in January, 1880 is described in considerable detail by Nelson (1899, pp. 366-379). It resembles the Anvik ceremony. 
4. Nelson's account is more detailed than Osgood's (1940, p. 423; 1958, p. 134) and differs from it in the apparently greater length of the ceremony described and the emphasis on the use of masks. Nelson (1899, pp. 379-393) also provides a detailed description of the equivalent, but more complex, ceremony as performed by the Eskimos of the Yukon-Kuskokwim region. Shageluk Island, referred to at the beginning of Nelson's description of the Anvik bladder festival, is a local name for the island formed by the Innoko and Yukon rivers and Shageluk Slough.

5. Osgood's account (1940, pp. 423-425; 1958, pp. 135-137) of the doll ceremony closely resembles this one, although he describes it as taking place in the fall as the first festival of the winter series. Nelson's reference to (Russian) Mission indicates that the ceremony was also performed by the Eskimos of Ikogmiut, but he was unable to obtain an account of the Eskimo version because the Russian Orthodox priest stationed at that settlement had been almost totally successful in preventing the people from performing it (Nelson, 1899, p. 379).

6. Osgood's account (1940, pp. 425-427; 1958, pp. 81-96) of this ceremony is far more detailed and complete. He also describes and illustrates masks used in the mask dance as does Chapman (1907, vol. II, pp. 16-32). Unlike Nelson, both these authors emphasize the importance of the Ingalik belief that the performance of a mask dance would increase the supply of economically important animals, characteristics of which were depicted in the dances.

7. This description of the preparation of a body after death is more detailed than Osgood's (1958, p. 151). The latter seems to indicate that the body was laid out in an extended position on a mat, but Parsons' (1921-1922, p. 69) informant describes the deceased as being propped in a seated position so that it could witness the events associated with mourning.

8. Osgood's (1958, p. 151) informant reported that the deceased was usually carried out through the door on its way to the kashim (Nelsons's "sweat house"), but later changed his mind and claimed that the body was always removed through the smoke hole. This procedure, confirmed by Parsons' (1921-1922, p. 69) informant, was repeated when the body was removed from the kashim (Osgood, 1940, p. 410).

9. According to Osgood $(1958$, pp. 149, 154), the body remained on 
a coffin rack near the cemetery to await the spring or fall burial season and was then interred in a coffin. This type of burial was considered most desirable, although Osgood (1958, pp. 149-151) describes other methods.

10. Osgood (1958, pp. 151-154) describes an elaborate ceremony in the kashim associated with coffin burial. The body is placed in the coffin on its back in a flexed position. Coffins, coffin houses, and the coffin rack are also described by Osgood (1940, pp. 409-414).

11. At the time of Nelson's visit, the village of Anvik was located on a flat point of land at the mouth of the Anvik River. The opposite bank of the river, site of the present village, is higher and the bluff below is the location of the present-day cemetery. No traditional coffins are now visible.

12. The coffins of shamans were often more carefully made than those of ordinary people and were sometimes elaborately ornamented (Parsons, 1921-1922, p. 70). Hrdlička (1944, p. 213) illustrates painted coffin houses which he encountered along the Innoko River.

13. See Osgood (1958, pp. 154-155). He does not mention a return by relatives to the grave or its reopening, although there could be gatherings around the coffin racks before burial (Osgood, 1940, p. $412 ; 1958$, p. 157). The large graveyard to which Nelson refers may have been associated with the village of Old Bonasila about 15 miles below Anvik on the same side of the river.

14. This special treatment for the graves of shamans is not reported in other sources, although Osgood (1940, pp. 414-415) does describe a specially constructed shaman's grave house.

15. Osgood $(1940$, pp. $415-416 ; 1958$, p. 150$)$ notes that the bodies of suicides, of individuals who were found frozen to death, murdered, or killed in war were cremated. The ashes were left undisturbed.

16. It is noteworthy that Nelson makes so many references to the opening of old graves when other sources fail to mention this practice.

17. See Osgood (1958, p. 156). He makes no mention, however, of self-mutilation.

18. This was probably a graveyard associated with the village of Holikachuk. Zagoskin visited this settlement, which he called 
Khuligichagat, in February, 1844, and noted five winter houses occupied by "not over 70 inhabitants of both sexes" (Zagoskin, 1967, pp. 235, 307). In 1880 Holikachuk was listed as having a population of 70 living in 12 houses (Archives of the Russian Orthodox Church in Alaska, parish records: Kvikhpak mission, church register). Although the photographs to which Nelson refers are no longer with the manuscript, a single negative in the photographic collections of the National Anthropological Archives entitled "Indian Graves on the Innoko River" would appear to have been taken by him on this trip and is reproduced here (fig. 3). A grave pole is described by Osgood (1940, p. 415).

19. See note 12. One of the grave boxes illustrated by Hrdlička (1944, p. 213) is decorated with paintings of caribou.

20. According to Osgood (1958, pp. 154-155), a person could indicate before his death whether he wished to have his personal possessions burned, placed in or near his coffin, or distributed to friends.

21. Neither Osgood nor Parsons mention offerings made at graves.

22. Possibly the now-abandoned village of Dementi located opposite the mouth of the Iditarod River. This settlement, called Ttality by Zagoskin (1967, pp. 236-237, 307), was visited by the explorer in February, 1844 at which time it consisted of three winter houses and had a population of 45 . Petr Kolmakov reached this settlement in 1839 and it was here that he learned of the destruction of the Ikogmiut post and decided to turn back. The inhabitants are said to have shown him the shortest route to the Kuskokwim (Zagoskin, 1967, p. 236).

23. Nelson obviously suspected that these beliefs were the result of teachings by the Russian Orthodox Church.

24. The sale of breech-loading firearms to the natives of Alaska was prohibited by law in 1875 and they rapidly became valuable items of contraband. Commercial whaling vessels which visited Kotzebue Sound and Norton Sound after 1850 traded these weapons to the coastal Eskimos who, in turn, traded them to the Ingalik and other Athapaskans. However, such weapons were also available at Alaska Commerical Company posts all along the middle and lower Yukon well before the order forbidding their importation 
was withdrawn in 1896 (Annual report of the Governor of Alaska for 1888, vol. 3, p. 994).

Both the moose and caribou populations of the lower Yukon appear to have fluctuated greatly in the nineteenth century. Zagoskin (1967, p. 238) described them as being "numberless" in the 1840's due to a plentiful food supply throughout the Ingalik area. In the spring of 1867 William Healy Dall, a member of the Western Union Telegraph Company Expedition, is said to have seen more than 4,000 skins of caribou fawns hanging up in a village near Anvik, but Nelson (1887, p. 286) observed that at the time of his travels fewer than half a dozen animals were taken in that area. Similarly, in 1869 Captain Charles Raymond $(1871$, p. 27) observed many large herds of caribou in the high country of the upper Anvik River, but by the mid-1880's and perhaps earlier the number of these animals had begun to decline (Nelson, 1887, pp. 237-238). Moose, on the other hand, appear to have declined by 1870 (Raymond, 1873, p. 171), but then reappeared and spread to the lower Yukon in the decade between 1870 and 1880 (Nelson, 1887, p. 287; Petroff, 1884, p. 5).

The decline in the numbers of moose and caribou is usually attributed by nineteenth-century observers, as Nelson does here and elsewhere, to the increased use of firearms, particularly the breechloading rifle (Raymond, 1871, p. 27; Petroff, 1884, p. 5; Nelson, 1887 , pp. 237-238, 288; Chapman, 1914, p. 3). Although the availability of firearms undoubtedly played a role at specific times, this explanation does not account for the reappearance of these animals in large numbers at later times and in different patterns. It is probable that habitat changes, particularly those caused by fire, were of greater importance than the use of firearms (VanStone, in press).

25. The taking of small game was of considerable importance to the Ingalik as it often provided virtually the only food available when supplies of dried fish were running low. The quantity of small game apparently varied considerably from year to year and when they were not plentiful, starvation or near-starvation could result. Bad floods in the spring frequently killed many small animals, a fact of which the Ingalik would be very much aware the following winter (Chapman, 1898, p. 573; Mertie and Harrington, 1924, p. 86; E. B. Lucas to J. W. Wood, April 27, 1926, Archives and Historical Collections, the Episcopal Church, Alaska papers, box 42).

26 . By the 1880 's steel traps appear to have been used fairly extensively in western Alaska, although in Zagoskin's time the Rus- 
sians had difficulty introducing them. The Indians preferred their traditional trapping methods and the iron parts of those traps which they did obtain were quickly converted into knives, hatchets, rings, and other useful items (Nelson, 1887, pp. 247-248, 279; Zagoskin, 1967, p. 221). It is clear, however, that traditional trapping methods were still in use at the time of Nelson's journey.

27. This statement concerning well-defined trapping territories inherited patrilineally is tantalizing and of considerable potential importance to an understanding of Ingalik social organization. However, the information cannot be verified in any other source.

28. Zagoskin (1967, p. 198) reported that black and brown bears were plentiful in the vicinity of Anvik and that these animals were hunted with pointed lances as they came out of hibernation in the early spring. Other methods of hunting bear are described by Osgood (1940, pp. 40-42; 1958, p. 244).

29. Dip net fishing is described by Osgood $(1958$, p. 236). The construction of traps is also described in some detail by Osgood (1940, pp. 226-227).

30. Since fishing was also an integral part of winter subsistence activities, serious famine occured only when there were failures of fish and game in winter and the salmon run in summer.

31. Although Osgood (1958, p. 237) refers to the ownership of fishing sites, he provides no details concerning the manner in which they were obtained or transferred from one generation to another.

32. The use of the gill net is described by Osgood (1940, pp. 214-215).

33. Fishing for loche or burbot (Lota lota) is described in detail by Osgood (1940, pp. 229-230; 1958, p. 241).

34. For other descriptions of lamprey fishing, see Chapman (1904, pp. 262-263), Osgood (1958, p. 40), and Zagoskin (1967, p. 203). Dip nets with a three-quarter-inch mesh were used for lampreys (Osgood, 1940, p. 211).

35. Glazunov was met at Anvik by Indians behaving in the manner described here by Nelson (VanStone, 1959, p. 43). When Zagoskin explored the Innoko in the winter of 1844, the inhabitants of the villages he visited were both friendly and helpful in spite of the fact that only a few years had elapsed since the smallpox epidemic of 1838-1839 for which native peoples held the Russians responsible (Zagoskin, 1967, pp. 231-242 passim, 248). 
36. The village referred to here is probably Holikachuk.

37. Population figures for the Yukon Ingalik villages obtained by Zagoskin (1967, p. 307) and Glazunov (VanStone, 1959) suggest that they may have lost fully two-thirds of their inhabitants as a result of the smallpox epidemic of 1838-1839. This is a much higher mortality rate than is apparent from the meager information available for other areas of west-central Alaska. It is probable that the adjacent Innoko River villages were similarly affected.

38. Trade networks involving the Ingalik and Norton Sound Eskimos were still functioning at the time of Nelson's travels as this story indicates. During the summer of 1879 when he was at St. Michael, Ingalik Indians from Anvik descended the Yukon in umiaks to exchange their well-made wooden bowls and dishes for seal oil and other coastal products (Nelson, 1899, p. 232). The Anvik River and its tributaries, however, were a much more common route to the coast for the Ingalik.

39. This is probably an exaggeration. See note 30 .

40. Nuklukayet was a Koyukon settlement and trading post at the mouth of the Tanana River near the present village of Tanana.

41. See Osgood (1959, pp. 68-73) for a fuller description of Ingalik attitudes toward property.

42. Osgood (1959, p. 69) notes that a rich man was often the object of jealousy on the part of less successful individuals. If a wealthy person did not share during times of hardship, he could be killed or have his cache robbed.

43. St. Michael had been the center of trade in western Alaska during the Russian period, but beginning in the early 1880's its role as a cosmopolitan center increased considerably. The more intensive trade of the Alaska Commerical Company gave the community an atmosphere of excitement and affluence that it had not enjoyed under the Russians. Beginning in late June, Indians and Eskimos gathered there hoping to trade with the company agents who had come down the Yukon to meet the annual supply ship. Natives who traded at St. Michael had an opportunity to choose from a trader's goods at a time when his stock was largest and most diverse. While waiting for the ship, the Eskimos and Indians traded with each other and, as Nelson notes here, took part in games, dancing, and other amusements (Elliott, 1886, pp. 413-414; Nelson, 1887, pp. 12-13; Porter, 1893, pp. 253-254). 
44. Osgood (1959, pp. 103-106) describes the Ingalik as believing in a four-level universe, two levels of which were beneath the surface of the ground. The one closest to the surface was the abode of the soul or yeg of most persons.

45. For a detailed discussion of blood revenge among the Ingalik, see Osgood (1958, pp. 53-56).

46. It is probable that early observers exaggerated the enmity existing between Eskimos and Indians in this area, although Nelson's statements are more balanced than most. Nineteenth-century Russian and American travelers may have been influenced in their judgement about relations between the two peoples more by casual conversations revealing ethnic prejudice than by actual evidence of warfare and violence which they witnessed or could confirm from reliable sources. Profitable trade relations existed between the Ingalik and their Eskimo neighbors (Osgood, 1958, pp. 28, 62; Zagoskin, 1967, pp. 137, 168, 191, 197) and the disruption of such relations for any length of time by bloody conflicts would seem unlikely. It is possible, of course, that hostilities between the Ingalik and Eskimos were reinforced by the Russian and American presence in the area.

47. This account is in essential agreement with Osgood's (1958, pp. 183-189) fuller statement. For a description of headbands worn during a girl's seclusion and other paraphernalia used in connection with menstruation, see Osgood (1940, pp. 406-408). A brief, personal account of a girl's seclusion at the time of her first menstruation is found in Parsons (1921-1922, pp. 57-58).

48. For a detailed account of childbirth, see Osgood (1958, pp. 171-173).

49. Osgood (1958, pp. 189-196) emphasizes the role of the boy's mother and grandmother in the selection of a wife. A modified form of bride service is reported by Parsons (1921-1922, p. 63). Postnuptial residence is not clearly defined by Osgood or other sources and it is probable that residence patterns were flexible and individual choice played a significant role as among other Athapaskan groups where bilaterality was characteristic. Thus Parsons (1921-1922, p. 61) notes that for the first two or three years after marriage a woman lived with her husband in her parents' home, after which the man built his own house in the immediate vicinity. Osgood's informants, on the other hand, reported that a 
young married man brought his wife to his parents' home for a period of time and then built his own house wherever he chose to do so (Osgood, 1958, pp. 196-198).

50 . Osgood $(1959$, pp. 53,204$)$ notes that wrestling was one of the commonest expressions of interpersonal aggression among the Ingalik and cites an example similar to the one described by Nelson.

51. It is clear from Osgood's (1958, pp. 56-61) discussion that a shaman was very jealous of his power, particularly with reference to other shamans in the same or neighboring villages. There are many recorded instances of conflict between shamans and the first missionaries to work among the Ingalik. The former struggled to maintain their prestige and hold on the people, while the latter frequently measured the success or failure of their efforts directly in terms of the extent to which they were able to triumph at the expense of the shamans (VanStone, in press).

52. Parsons' (1921-1922, p. 54) Ingalik informant mentioned a number of traditional practices that were apparently still carried out as late as the early 1920's. Birds were plucked and animals skinned and disemboweled before they were sold to the Anvik mission, and the meat of bears and lynx was not sold to white people.

53. The skin of the wolverine was highly valued by the Ingalik and served primarily for decoration. A successful trapper of these resourceful and dangerous animals gained considerable prestige (Osgood, 1958, p. 247). Nelson (1887, pp. 248-249) includes this story about the profane trapper in his published account of the wolverine and its habits.

54. Until the mid-1960's the village of Shageluk was located along a narrow strip of land separating Shageluk Lake from the Innoko River. By 1972 most residents had moved to a new location approximately 2 miles down river. Giant fish are a common element in the Alaskan Eskimo nonempirical environment (Burch, 1971, p. 156).

55. Nelson's comments concerning clothing worn by Indians on the upper Innoko River were equally applicable to the Ingalik and other Yukon peoples. From the earliest days of the fur trade, attempts were made to discourage the Indians from using valuable furs for clothing. When Zagoskin was at Nulato he noted that some Indians who visited the trading station began to observe the definite advantages of the summer clothing worn by members of the expedition. Therefore, they began to ask the manager for calico 
shirts, blankets, cloth dresses, and caps, and some even wanted shoes (Zagoskin, 1967, p. 185). By the late 1880's cotton drilling, unbleached muslin, and calico were staple items of trade at Anvik (J. W. Chapman to W. S. Langford, July 27, 1887, Archives and Historical Collections, the Episcopal Church, Alaska papers, box 15).

56. A legacy from the Russians, and later the Americans, to the Eskimo and Indian population of west-central Alaska was the introduction of communicable diseases which spread rapidly and decimated a population with no opportunity to build up an immunity to them. The smallpox epidemic of 1838-1839 may have been unique in the early years of European contact. However, epidemics and other periods of illness, some severe and others of short duration, not only continued in west-central Alaska but increased as the native population was increasingly exposed to contact with outsiders.

Population figures for the Innoko River in the late nineteenth century are difficult to ascertain, in part because of the confusing terminology characteristic of historical source materials for the area. Zagoskin (1967, p. 307) lists six settlements on the Innoko River below the entrance of Holikachuk Slough. The combined population of five of these was 285 in 1844 . The tenth federal census in 1880 enumerated 150 persons living on "Chageluk slough and Innok river" (Petroff, 1884, p. 12). Nelson's figure presumably refers only to those living above the confluence of the Innoko River and Holikachuk Slough. However, as noted in the introduction, there is no way of knowing how far up the Innoko River his explorations extended.

57. In some respects, the structure described and illustrated by Nelson more closely resembles an Eskimo kashim in southwestern Alaska (VanStone, 1968, pp. 252-258; 1970, pp. 33, 35-38) than it does the Ingalik kashim described by Osgood (1940, pp. 290-302). Nelson's statement about the antiquity of kashims in Innoko villages is probably inaccurate, but, in fact, the definite existence of prehistoric structures of this type in settlements along the river has not been documented.

58. This would appear to be another reference to Dementi, although elsewhere Nelson mentions a settlement, presumably Holikachuk, at the mouth of the Innoko (see p. 31, note 18). Osgood $(1958$, p. 30$)$ noted that Ingalik summer villages were frequently 
built on lower land directly in front of winter settlements.

59. The manufacture of pottery by the Ingalik is described by Osgood (1940, pp. 146-419). DeLaguna (1947, pp. 140-149, figs. 26-33, pls. xxii-xxiv) describes and illustrates pot and lamp fragments which she excavated in the area in the summer of 1935. The great majority of decorated sherds belong to the Yukon Lined and Line-dot types, styles of surface treatment indentified at Eskimo sites on the coast (Oswalt, 1955, pp. 37-38).

60. See note 38. The manufacture of birch bark canoes by the Ingalik is described in detail by Osgood (1940, pp. 359-373). He notes that umiaks based on the Eskimo type from St. Michael (Nelson, 1899 , pls. Ixxvii, lxxviii, 38) were occasionally constructed by wealthy Ingalik or purchased by them from the Eskimos (Osgood, 1940 , p. 380).

61. In western Alaska jade is found only on the Kobuk River and on Seward Peninsula, but it was traded extensively (see Nelson, 1884 , pp. $426-427 ; 1899$, p. 230).

62. At the beginning of the American period, Dall (1870, p. 499) noted that beaver pelts were the traders' standard of value as they had been during the Russian period, and that one pelt was worth 20 lead balls or 2 fathoms of strung beads. Four mink pelts, two marten, or two white fox were equal in value to a beaver. By 1885 the unit of trade in the Yukon district was the pelt of a red fox or marten and its cash value was $\$ 1.25$ (Porter, 1839, p. 120). According to these rates, a prime beaver pelt was worth two "skins"; a black bear, four; a lynx, one; and a land otter, two or three "skins," depending on condition. Items of trade that could be obtained with one "skin" included $5 \mathrm{yds}$. of drilling, $1 \mathrm{lb}$. of tea or gunpowder, onehalf pound of powder and a box of caps, $1 \mathrm{lb}$. of shot, and $5 \mathrm{lbs}$. of sugar. A 50 lb. sack of flour could be obtained for four "skins."

63. Two shorter and somewhat different versions of this story have been recorded by Chapman (1914, pp. 28-32).

64. This story is not duplicated in other collections of folk tales from the Ingalik and neighboring peoples.

65. This story has some elements in common with one obtained by Nelson at Andreavsky and said to be known all along the lower Yukon (Nelson, 1899, pp. 488-490). Although the description of the land of the dead in this Anvik story differs somewhat from other Ingalik accounts (Chapman, 1914, pp. 8-10; Osgood, 1959, pp. 
103-106), it shares with them references to the ability, once possessed by human beings, to return from the dead.

66. This story is not recorded in other compilations of myths from the lower Yukon. Shamanistic rivalry, however, is a characteristic feature of Eskimo and Indian stories.

67. Stories in which Raven brings the light are recounted for the Koyukon (Jetté, 1908, pp. 304-305), the Eskimos of Paimiut (Nelson, 1899, pp. 483-485), and the Ingalik (Chapman, 1914, pp. 22-26). The latter account is closest to the version given here. 


\section{REFERENCES}

\section{Archives and Historical Collections, the Episcopal Church}

MS. Alaska papers of the domestic and foreign missionary society, 1884-1952, 105 boxes. Episcopal Seminary of the Southwest, Austin, Texas.

ARchives of the Russian Orthodox Church in Alaska

MS. Parish records: Kvikhpak mission, church register. Xerox copy in the Alaska Historical Library, Juneau.

Burch, E. S. JR.

1971. The nonempirical environment of the arctic Alaskan Eskimos. Southwestern Jour. Anthropol., 27, no. 2, pp. 148-165.

Chapman, J. W.

1898. Annual report of Christ Church Mission. Spirit of Missions, 64, pp. 572-573.

1904. The Yukon River and its value to the Alaska mission. Spirit of Missions, 69, pp. 260-264.

1907. Notes on the Tinneh tribe of Anvik, Alaska. Congr. Int. Amer., $x^{\mathbf{e}}$ session, 2, pp. 7-38.

1914. Ten'a texts and tales from Anvik, Alaska. Publ. Amer. Ethnol. Soc., 6.

Chernenko, M. B.

1967. Lavrentiy Alekseyevich Zagoskin. An account of his life and works. In: Michael, Henry N., ed., Lieutenant Zagoskin's travels in Russian America, 18421844. The first ethnographic and geographic investigations in the Yukon and Kuskokwim valleys of Alaska, Arctic Institute of North America, anthropology of the north, translations from Russian sources, no. 7. Toronto.

DALL, W. H.

1870. Alaska and its resources. Lee and Shepard, Boston.

DeLaguna, F.

1947. The prehistory of North America as seen from the Yukon. Mem. Soc. Amer. Archaeol., no. 3.

ELLIOTT, H. W.

1886. Our arctic province, Alaska and the Seal Islands. Charles Scribner's Sons, New York.

Fedorova, S. G.

1973a. New data on Russian geographic and ethnographic investigations in 
Alaska (first half of the 19th century). Paper presented at the IX Int. Cong. Anthropol. Ethnol. Sci., Chicago. Sept., 1973.

1973b. The Russian population in Alaska and California. Late 18th century -1867.

Translated and edited by R. A. Pierce and A. S. Donnelly. Materials for the study of Alaskan history, no. 4. Kingston, Ontario.

Goldman, E. A.

1935. Edward William Nelson - naturalist, 1855-1934. Auk, 52, no. 2, pp. 135-148.

HAWKES, E. W.

1913. The "Inviting-In" feast of the Alaskan Eskimo. Canada, Dept. of Mines,

Geol. Survey, memoir 45, no. 3, anthropol. ser. Ottawa.

Hosley, E.

1968. The Kolchan: delineation of a new northern Athapaskan Indian group. Arctic, 21, no. 1, pp. 6-11.

HRDLIČKA, A.

1944. Alaska diary 1926-1931. The Jacques Cattell Press, Lancaster, Pa.

JETTÉ, J.

1908. On Ten'a folk-lore. Jour. Royal Anthropol. Inst., 38, pp. 298-367.

Kraus, M. E.

1974. Native peoples and languages of Alaska (map). Alaska Native Language

Center, University of Alaska.

LANTIS, M.

1954. Edward William Nelson. Anthropol. Pap. Univ. Alaska, 3, no. 1, pp. 5-16.

Mertie, J. B. AND G. L. Harrington

1924. The Ruby-Kuskokwim region, Alaska. U.S. Geol. Surv., bull. 754. Washington.

NELSON, E. W.

1884. On the source of the jadeite implements of the Alaskan Innuits. Proc. U.S. Nat. Mus., 6, 1883, pp. 426-427.

1887. Report upon natural history collections made in Alaska between the years 1877 and 1881. Washington.

1899. The Eskimo about Bering Strait. Eighteenth annual report, Bur. Amer. Ethnol., pt. 1. Washington.

OSGOOD, C.

1940. Ingalik material culture. Yale Univ. Publ. Anthropol., no. 22. New Haven. 1958. Ingalik social culture. Yale Univ. Publ. Anthropol., no. 53. New Haven.

1959. Ingalik mental culture. Yale Univ. Publ. Anthropol., no. 56. New Haven.

OSWALT, W. H.

1955. Alaskan pottery: a classification and historical reconstruction. Amer.

Antiquity, 21, no. 1, pp. 32.43. 
OsWALT, W. H., ed.

1960. Eskimos and Indians of western Alaska 1861-1868: extracts from the diary of Father Illarion. Anthropol. Pap. Univ. Alaska, 8, no. 2, pp. 101-118.

PARSONS, E. C.

1921-1922. A narrative of the Ten'a of Anvik, Alaska. Anthropos, 16-17, pp. 51-71.

Petroff, I.

1884. Report on population, industries and resources of Alaska. Washington.

PORTER, R. P., comp.

1893. Report on population and resources of Alaska at the 11th census: 1890 . Washington.

RAYMOND, C. W.

1871. Report of a reconnaissance of the Yukon River, Alaska Territory. July to September, 1869. 42nd Congress, 1st session, Senate exec. doc. no. 12. Washington.

1873. The Yukon River region of Alaska. Jour. Amer. Geogr. Soc., 1870-1871, pp. 158-192.

RUSSIAN-AMERICAN COMPANY RECORDS

MS. 1802-1867: communications sent. File microcopies of records in the U. S. National Archives, no. 11. Washington.

SHERWOOD, M.

1965. Exploration of Alaska: 1865-1900. Yale Univ. Press.

United States Department of the Interior. Annual Report of the Governor of Alaska

1888. Report of the Governor of Alaska for 1888, vol. 3, pp. 959-1,012.

VANSTONE, J. W.

1959. Russian exploration in interior Alaska. An extract from the journal of Andrei Glazunov. Pacific Northwest Quart., 50, no. 2, pp. 37-47.

1967. Eskimos of the Nushagak River: an ethnographic history. Univ. Wash. Press.

1968. Tikchik village: a nineteenth century riverine community in southwestern Alaska. Fieldiana: Anthropol., 56, no. 3, pp. 215-368.

1970. Akulivikchuk: a nineteenth century Eskimo village on the Nushagak River, Alaska. Fieldiana, Anthropol., 60.

IN PRESS. Ingalik contact ecology: an ethnohistory of the lower-middle Yukon, 1790-1935. Fieldiana: Anthropol.

WHYMPER, F.

1869. Travel and adventure in the territory of Alaska. Harper \& Brothers, New York.

Wrangell, F. P. von

1970. The inhabitants of the northwest coast of Alaska. Translated and edited by James W. VanStone. Arctic Anthropol., 6, no. 2, pp. 5-20. 


\section{ZAGoskin, L. A.}

1956. Puteshestviya i issledovaniya leytenanta Lavrentiya Zagoskina v Russkoy Amerike v 1842-1844 g.g. Editing, notes, and commentary by M. B. Chernenko, G. A. Agranat, and Y. E. Blomkvist. State Publishing House of Geographic Literature, Moscow.

1967. Lieutenant Zagoskin's travels in Russian America, 1842-1844. The first ethnographic and geographic investigations in the Yukon and Kuskokwim valleys of Alaska. Edited by Henry M. Michael. Arctic Institute of North America, anthropology of the north, translations from Russian sources, no. 7. Toronto. 


\section{INDEX}

Ahtna Indians, 12

Alaska Commercial Co., 67, 68

Andreavsky, 72

Anilukhtakpak. See Holy Cross

Anvik River, 3, 8, 10, 11, 36, 38, 46; as route to the coast for Ingalik Indians, 68

Anvik village, 3, 5, 10, 11, 14, 37, 47, 66,67 ; cemetery at, 29; cemetery near, 29-30; ceremonies at, 17, 18, 21-28; description of, 46 ; location of, 64

\section{Baird, Spence, 7, 8}

Bethel, 4

Bladder festival: activities of messengers during, 17; analysis of, 25; borrowed from Eskimo, 17, 22, 25

Bonasila, 3, 11

Bristol Bay, 17

Buckland River, 4, 5

Caribou: fluctuations of populations in 19th century, 66; hunting of, 34; reasons for population decline, 66; significance of habitat changes for, 66

Chagelyuk River. See Innoko River

Cook Inlet, 1, 3, 4, 12

Dall, William H., 66, 72

Death, behavior of relatives of deceased at time of, $30,31,33,64$

Dementi, 4, 65, 71

Elliott, Henry W., 7

Episcopal Church: mission on lower Yukon, 11
Eskimo: influenced culture of Ingalik, 14, 15; trade with Ingalik Indians, $65,68,69$; warfare against Indians, 41,69

Fishing: methods of, $36-37$

Fort Yukon, 6, 43, 44

Fox Point Island, 8

Fredericks, S. A., 10; accompanies Nelson, 1,8

Fur trade: development of, 14; expansion of, 3 ; units of value in, 47

Georgetown, 11

Glazunov, A., 3, 12, 68; explorations of, 1,67

Goltsan. See Kolchan Indians

Grayling village, 10; home of former Holikachuk residents, 13

Holikachuk: tribal designation, 13

Holikachuk Slough, 8, 9, 10, 71

Holikachuk village, $8,10,65,71$; cemetery at, 64; cultural and linguistic affiliation of, 13

Holy Cross, 3, 5, 11

Hosley, E., research on Ingalik, 13

Hudson's Bay Co., 7

Iditarod River, 4, 5, 65

Ikogmiut, 3, 4, 5, 27; destruction of, 4; Russian Orthodox mission at, 12,65

Iliamna Lake, 1

Illarion, Hieromonk, 13; interest in native peoples, 12

Ingalik Indians: attitudes toward children, 40; attitudes toward fur traders, 38, 67; attitudes toward 
game, 43, 70; attitudes toward property, 39, 68; bear hunting by, 67; behavior of relatives of deceased, 30 31,33 ; belief in land of the dead, 69 ; blood revenge among, 69 ; burial of shamans by, 30 ; cemeteries of, 29 , $30,31,64,65$; ceremonies of, 14,17 , 18-28, 62, 63; childbirth among, 42; culture influenced by Eskimo, 14, 15; dip net fishing by, 67; fear of witchcraft among, 39; fondness for singing and dancing, 68 ; girls' puberty rites of, 41-42, 69; grave boxes of, $29,31,33,64,65$; importance of small game to, 66; interpersonal aggression among, 70; lamprey fishing by, 37, 67; legends of, 47-56, 61, 72-73; manufacture of canoes by, 46,72 ; manufacture of wooden vessels by, 46; marriage among, 42 , 69; occupation of Kuskokwim valley by, 12; ownership of fishing sites by, 36,67 ; pottery making by, 46,72 ; resemblance of houses to those of Eskimo, 46; residence patterns of, 69,70 ; role of shamans among, 31 , 43,70 ; settlements of, $64,65,68$, 70,71 ; subdivisions of, 11 ; superstitions of, 44; trade with Eskimos, $14,34,38,47,65,68,69$; trapping by, $34,35,36,66-67$; trapping territories of, $35,36,67$; treatment of body at death, 28, 63; use of firearms by, 65 , 66 ; use of masks by, 27,28 ; use of umiak by, 46, 72; weapons of, 34 ; wrestling for wives among, 42 Innoka River. See Innoko River Innoko River: confusing geographical nomenclature of, 8-9, 10; cultural and linguistic characteristics of inhabitants, 13; exploration of, $3,4,5$, 8,10 ; meaning of name, 10 ; population of, 71; settlements on, 71. See also Tlëgon River

Innoko River Indians: settlements of, $46,65,68$

Ittege River. See Innoko River

Jade: importance as trade item, 72
Kashim: antiquity of on Innoko River, 71; decorated during bladder festival, 23-24; decorated for doll festival, 25-26; description of, 45-46, 71

Khuligichagat. See Holikachuk village Kobuk River, 72

Kokrines, 5

Kolchan Indians: description of kashim among, 45, 46; dress of, 44; population decline of, 45; usage as tribal name, 12-13

Kolmakov, Fedor, 4

Kolmakov, Petr F., 5, 10, 12, 13, 65; explorations by, 4

Kolmakovskiy Redoubt, 3

Kotzebue Sound, 4, 5, 40, 65

Koyukon Indians, 11, 13, 14; bear hunting by, 36; ceremonies of, 62; legends of, 56-61; trade by, 47

Koyukuk River, 3, 5

Kraus, M.: linguistic research of, 13

Kuskokwim River, 3, 4, 5, 10, 11

Kyltchanes. See Kolchan Indians

Lime Hills, 3

Magimiut. See Old Bonasila

Malakhov, Petr V., 5; explorations of, 3-4

Malemiut: relations with Yukon Indians, 40, 41; trade with Ingalik, 34

McGrath, 4, 11

McQuesten. L. N.: provides information to Nelson, 11

Messengers: activities during bladder festival, 17

Mikhailovskiy Redoubt, 1, 3, 4, 6. See also St. Michael

Missionaries: relations with shamans, 70

Moose: fluctuations of population in 19th century, 66; hunting of, 34 ; reasons for population decline, 66; significance of habitat changes for, 66

Nelson, Edward W.: assigned to St. Michael, 7, 8; early life, 7; explorations of, 8, 10; evaluation of his 
notes, 11-15; interest in natural history, 7, 8; later life of, 10-11; leaves Alaska, 10; makes collection of Eskimo ethnographic specimens, 8; obtains information from L. N. McQuesten, 11; publishes "Eskimo about Bering Strait," 11; route followed by, 8, 10

Norton Sound, 1, 14, 40, 65, 68

Nowitna River, 5

Nuklukayet, 68; famine at, 39, 44

Nulato, 3, 5, 6, 11, 37, 40, 43, 47, 70

Nushagak River, 3, 4

Old Bonasila, 3; cemetery at, 64

Osgood, Cornelius: research on Ingalik Indians, 11, 12, 13, 14

Paimiut, 5, 47

Pilot Station, 62

Prince William Sound, 12

Raymond, Capt. Charles W., 66; explorations by, 6

Razbinsky, 62

Roman Catholic Church: mission on lower Yukon, 11

Russian-American Co., 1, 3, 4, 6

Russian Mission. See Ikogmiut

St. Michael, 6, 7, 10, 38, 39, 72; importance as trading center, 68. See also Mikhailovskiy Redoubt

Seward Peninsula, 72

Shageluk Island, 22, 27, 33, 46, 63

Shageluk Láke, 70

Shageluk River. See Innoko River

Shageluk Slough, 3, 7, 8, 63, 64

Shageluk village, $8,11,21,70$

Shagelyk Slough. See Shageluk Slough

Shamans: attitudes toward death of, 31 ; burial of, 30,64 ; relations with missionaries, 70; role among Ingalik, 70

Shiltonotno River. See Innoko River

Signal Service, 7

Smallpox: epidemic of 1838-1839, 4, $67,68,71$
Stony River, 3, 4, 12

Swift River, 12

Takotna River, 4

Tanaina Indians, 12, 14

Tanana Indians, 14; attitude toward game of, 43; attitude toward traders of, 43

Tanana River, 11, 68

Tanana village, 68

Tatlawiksuk River, 12

Tlëgon River, 4, 10. See also Innoko River

Trapping: methods of, 3435,46 , 66-67; season of, 34 ; territories, 35 , 36,67

Ttality. See Dementi

Unalakleet River, 3, 5

Upper Innoko Indians, 5

Upper Kuskokwim: tribal designation, 13

Western Union Telegraph Co. Expedition, 7, 66; explorations by members of, 6

Wrangell, Baron F. P. von, 12

Yukon Delta, 1, 3

Yukon Indians: belief in land of the dead, 40; blood vengeance among, 40; borrowing from Eskimo by, 47; dress of, 44, 70-71; famine among, $36,39,67$; fishing methods of, 36 , 37; fondness for singing and dancing, 39 ; population decline of, 44 ; relations with Malemiut, 40, 41; respect for aged among, 42, 43; superstitions of, 43, 44; units of value in trading, 72; value of furs to, 47; warfare with Eskimos, 41, 69

Yukon River: evaluation of explorations of, 7; explorations of, $1,3,4,5$, 6,8

Zagoskin, Lieut. L. A., 1, 9, 12, 64, 65, $67,68,70,71$; explorations of, 4, 5, 6; his use of the term Kolchan, 13 







